Gerión. Revista de Historia Antigua

ISSN: 0213-0181

https://dx.doi.org/10.5209/geri.74794

\title{
El programa iconográfico de los mosaicos de la villa romana de "El Alcaparral" (Casariche, Sevilla) en el conventus Astigitanus ${ }^{1}$
}

\author{
Luz Neira Jiménez ${ }^{2}$
}

Recibido: 28 de abril de 2020 / Aceptado: 12 de noviembre de 2020

Resumen. Este trabajo aborda el análisis del programa iconográfico de los mosaicos que pavimentaban el edificio señorial de la villa de "El Alcaparral" (Casariche, Sevilla), un conjunto de 15 pavimentos descubiertos en las campañas de 1985 y 1986, entre los que, junto al célebre del Juicio de Paris, se cuentan un fragmentario mosaico de thiasos marino con nereidas, un mosaico con una representación alegórica y pavimentos de tema geométrico en diferente estado, algunos de los cuales se conservan en la Colección Museográfica del Mosaico Romano de Casariche. Se trata de obtener no sólo una imagen completa del programa musivo sino también del contexto arquitectónico de la villa de "El Alcaparral" y la mentalidad de su dominus.

Palabras Clave: villae; mosaicos romanos; Juicio de Paris; Nereidas; alegoría; esquemas geométricos.

\section{[en] The Iconographic Program of the Mosaics from the Roman villa of "El Alcaparral" (Casariche, Seville) in the conventus Astigitanus}

Abstract. This work deals with the analysis of the iconographic program of the mosaics that paved the main building of the villa of "El Alcaparral" (Casariche, Seville). They are 15 pavements discovered in the archaeological excavations performed in the site in 1985 and 1986. Among the mosaics discussed, the mosaic of Paris, the fragmentary mosaic of the marine thiasos with nereids, a mosaic with an allegorical depiction and pavements with geometric schemes, some of the which are preserved in the Casariche Museum Colection. In order to obtain not only a full picture of the mosaic program but also of the architectural context of the villa "El Alcaparral" and the mentality of its dominus.

Keywords: Villae; Roman Mosaics; Judgement of Paris; Nereids; Allegoric Personification; Geometric Schemes.

Sumario. 1. Introducción. 2. Los mosaicos de la villa "El Alcaparral". 3. Consideraciones sobre el programa iconográfico de la decoración musiva de la villa de "El Alcaparral". 4. Referencias bibliográficas.

\footnotetext{
Este trabajo es resultado del Proyecto de Investigación de I+D+i "Patrimonio Arqueológico, Nuevas Tecnologías, Turismo, Educación y Rentabilización Social: un nexo necesario para el yacimiento rural (PATTERN)", de la convocatoria Retos de la Sociedad 2015 - HAR2015-68059-C2-2-R, financiado por el Ministerio de Economía y Competitividad (MINECO, FEDER, UE) y del que he sido IP en la Universidad Carlos III de Madrid. Deseo hacer constar aquí todo mi agradecimiento a Antonio García, director de la Colección Museográfica del Mosaico Romano de Casariche, quien gentilmente me ha facilitado las fotografías realizadas durante las campañas de excavación en "El Alcaparral", de gran interés para la reconstitución de la villa y sus mosaicos.

2 Universidad Carlos III de Madrid.

E-mail:1neira@hum.uc3m.es

ORCID: 0000-0002-2421-6792
} 
Cómo citar: Neira Jiménez, L. (2021): El programa iconográfico de los mosaicos de la villa romana de "El Alcaparral" (Casariche, Sevilla) en el conventus Astigitanus, en Gerión 39/1, 303-336.

\section{Introducción}

A mediados de julio de 1985, el hallazgo de un mosaico en la finca denominada "El Alcaparral" en el término municipal de Casariche (Sevilla), ${ }^{3}$ a unos $3 \mathrm{~km}$ de su núcleo urbano, fue comunicado a la Delegación Provincial de Cultura de Sevilla, lo que propició el inicio de una excavación de urgencia en el mismo verano de 1985, de cuyos resultados dieron cuenta en aquel año los arqueólogos responsables de la campaña. ${ }^{4}$ Por fortuna, la labor realizada no se limitó al célebre mosaico con la representación del Juicio de Paris que se conservaba en bastante buen estado, sino que se amplió a las zonas colindantes, donde se constataron, además de la existencia de restos arquitectónicos, cerámicos, vítreos y metálicos, varios mosaicos más, preludiando el conocimiento de un dominio rural de gran importancia en el conventus Astigitanus en el marco de la Baetica.

A este respecto, los autores ${ }^{5}$ del informe de aquella excavación mencionaron el hallazgo de seis mosaicos más, numerados del 2 al 7, aunque fuera parcial en el caso de $\operatorname{los} \mathrm{n}^{\circ} 2,6$ y 7 por encontrarse en parte fuera del área delimitada en la campaña de 1985, especificando el mal estado en el que se encontraba el $\mathrm{n}^{\circ} 4$. Asimismo, los arqueólogos señalaron cómo en el cuadro 1 situado en el extrarradio fueron hallados muros que delimitaban una estancia y en su interior una pequeña pileta excavada en el suelo, con las paredes revestidas por cuatro tégulas, y en torno a esta pileta una ocultación de 74 monedas, de época tardía, muchas de ellas de cecas orientales, y las dos piezas cerámicas de sigillata africana C y D. ${ }^{6}$ Como colofón a la campaña, todos los mosaicos fueron dejados in situ y cubiertos de nuevo en un área vallada y protegida.

La significación de todos estos hallazgos fue fundamental a la hora de proseguir las excavaciones en la finca "El Alcaparral" un año después, durante el verano de 1986, gracias a la financiación del Ayuntamiento de Casariche. En la segunda campaña los arqueólogos hallaron un número mayor de estructuras, según su opinión de la pars urbana de la villa, con una planimetría en tres terrazas, si bien la mayoría de los mosaicos descubiertos, hasta sumar un número total de 15 pavimentos, se encontraba en la terraza media, a excepción del $\mathrm{n}^{\mathrm{0}} 7$ y el $\mathrm{n}^{\mathrm{o}} 15,{ }^{7}$ completando su informe con una planta del edificio con las estancias excavadas, en las que se consignó cada pavimento hallado, con la parte conservada y la zona destruida o muy lagunosa de los mosaicos. En esta línea, fueron mencionadas también las reparaciones de peor factura que algunos de ellos presentaban, en particular $\operatorname{los} \mathrm{n}^{\circ} 2$ y 13 , este último

Los pormenores del hallazgo aparecen relatados por Francisco Estepa López en 2010 en http://historiadecasariche. blogspot.com/p/juicio-de-paris-mosaico.html [Consultado el 9 de abril de 2020].

Jiménez et alii 1985, 274-276.

Jiménez et alii 1985, 276, láms. I-II.

Jiménez et alii 1985, 275-276.

De la Hoz - Jiménez 1986, 373-379, figs. 4-5. 
incluso "con hileras de ladrillos colocadas lateralmente para proteger el borde en una zona de paso".

Como resultado de esta segunda campaña, los arqueólogos plantearon una cronología en virtud del hallazgo de una moneda de Filipo el Árabe (244-249) sobre el mosaico $\mathrm{n}^{\circ} 14$, que, según ellos, aportaría una fecha de inicio para la villa, mientras que, entre aquellas descubiertas fuera del "recinto" como resultado de una ocultación, una de Honorio, cuya amonedación data del 393-395 o 395-408, permitiría plantear para la destrucción y abandono un periodo entre mediados del siglo IV y principios del V, época a la que atribuyeron la sigillata $\mathrm{C}$ y D hallada en la primera campaña. ${ }^{8}$

Tras la segunda campaña de 1986, el yacimiento y los mosaicos fueron cubiertos de nuevo y conservados in situ. Hasta noviembre de 2000, fecha en la que se llevó a cabo la extracción de 11 mosaicos, ${ }^{9}$ si bien el plan inicial preveía solo el levantamiento del mosaico con la representación del Juicio de Paris, que fue depositado en dependencias del Ayuntamiento de Casariche, mientras los diez mosaicos restantes fueron trasladados a los almacenes de la Delegación Provincial de Cultura de Sevilla.

Con posterioridad, el mosaico del Juicio de Paris fue trasladado al Museo Arqueológico Provincial de Sevilla. No obstante, tras la inauguración en 2014 de un edificio en el centro urbano de Casariche que albergaría la Colección Museográfica del Mosaico Romano y las reivindicaciones de los casaricheños solicitando el regreso del mosaico a Casariche, el pavimento se conserva desde el 22 de julio de 2017 en la citada Colección, donde también figuran expuestos otros cinco de los mosaicos hallados en "El Alcaparral".

En la actualidad, dado nuestro interés científico por los mosaicos de las villae de la Baetica y en concreto del conventus Astigitanus, ${ }^{10}$ consideramos que el esfuerzo museográfico realizado en Casariche para poner en valor los hallazgos de la denominada villa de "El Alcaparral" y la representatividad de sus pavimentos como reflejo de una residencia en el contexto rural merecen una investigación que, "revisitando" el yacimiento, arroje luz sobre las pretensiones del dominus de "El Alcaparral".

Para ello, y dada la ausencia de excavaciones posteriores a 1986 en la villa, ${ }^{11}$ salvo las tareas destinadas en 2000 a la extracción de los mosaicos, nos basaremos en el plano ofrecido por los arqueólogos De la Hoz y Jiménez ${ }^{12}$ (Fig. 1), comenzando

De la Hoz - Jiménez 1986, 377.

9 Así consta en la Memoria de Extracción de los mosaicos del yacimiento de la villa romana del Alcaparral. Casariche. Sevilla, realizada por GARES. S.L., cuya copia nos ha facilitado gentilmente Antonio García, director de la Colección Museográfica del Mosaico Romano de Casariche.

10 Caso de Fuente Álamo, en Puente Genil (Córdoba); Neira 2019, 279-322.

11 Carrillo 1993, señalaba ya ese incoveniente. Recientemente, un corpus dedicado a las villae de la Bética ha sido publicado (Hidalgo, 2017), mencionándose algunos de los pavimentos de "El Alcaparral" en la síntesis temática sobre la decoración musiva de las villae béticas (Vargas - López Monteagudo 2017, 425, 427, 428, figs. 3, 10, 12 y 19). Frente a la clasificación y denominación de diseños geométricos empleada en Vargas 2013, consideramos aquí como referencia idónea los dos magníficos volúmenes de Le Décor géométrique de la mosaïque romaine, de 1985 y 2002, que registran los repertorios de motivos y esquemas geométricos que aparecen documentados en los mosaicos romanos de todo el Imperio y cuya terminología fue homogeneizada en francés, inglés, alemán, italiano y español.

12 De la Hoz - Jiménez 1986, 376, fig. 4. 
por el pavimento de la primera estancia conservada más próxima al ingreso, es decir, por el mosaico $\mathrm{n}^{\mathrm{o}} 1 .^{13}$

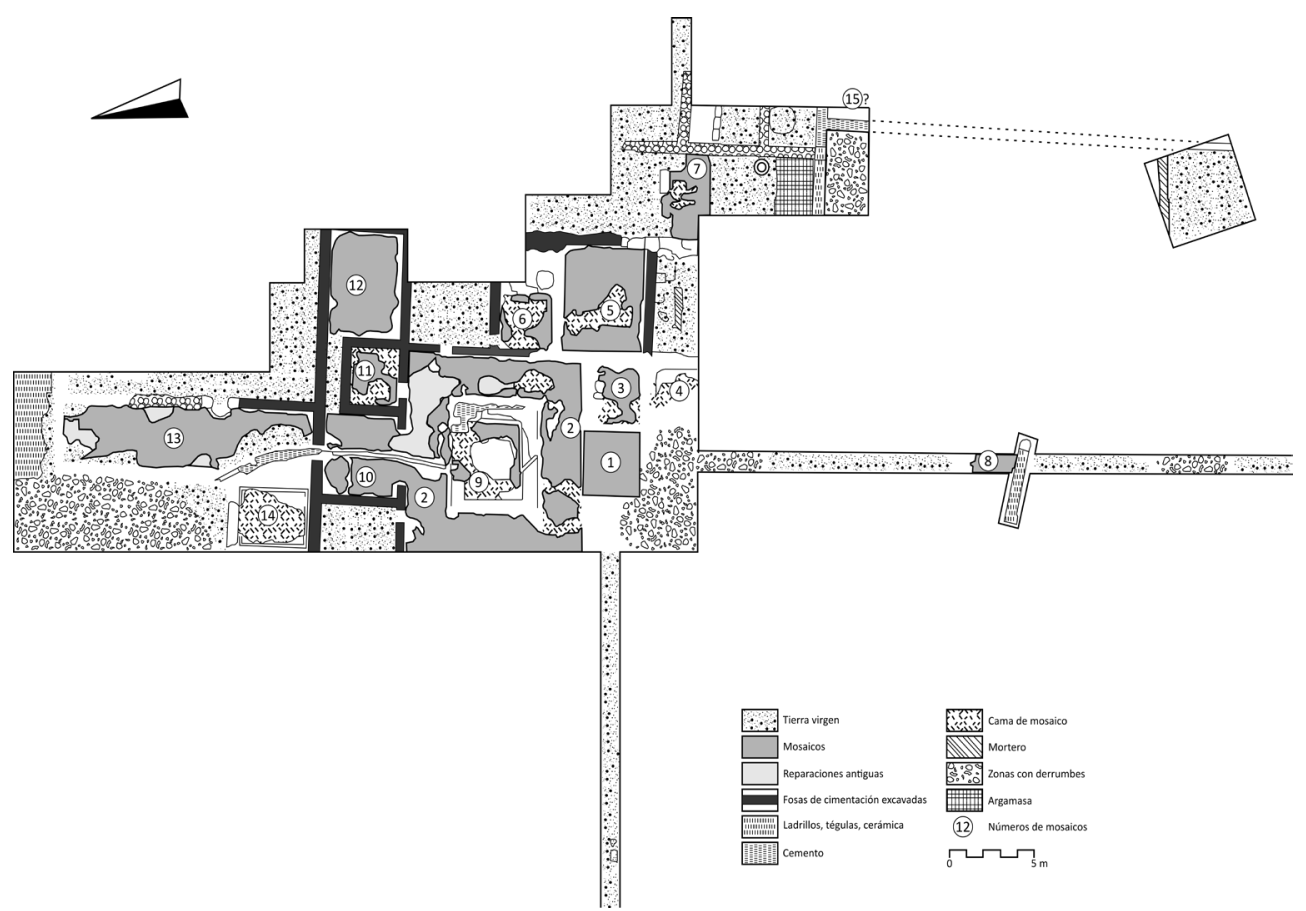

Fig. 1. Plano de la villa de "El Alcaparral", Casariche, Sevilla (Fernando Moreno según De la Hoz - Jiménez 1986, 376)

\section{Los mosaicos de la villa de "El Alcaparral"}

Entre los datos más sobresalientes que la primera campaña proporcionó, ${ }^{14}$ es preciso resaltar la excavación parcial, a través de una cata, del lecho del célebre mosaico y la constatación de que este se encontraba sobre un pavimento anterior, a $10 \mathrm{~cm}$, desvelando que el mosaico del Juicio debió formar parte de un proceso de monumentalización del edificio residencial de la villa, que por tanto debió tener una fase anterior, sobre cuya ocupación volveremos al final del estudio de todos los mosaicos.

Centrándonos en el pavimento, la noticia de su hallazgo, con una representación de la mitología bien conocida en el mundo clásico y difundida a lo largo de la historia, no obstante, única en aquel momento en la musivaria hispanorromana, fue muy pronto objeto de interés entre los investigadores dedicados al estudio de la Antigüedad y los mosaicos romanos ${ }^{15}$ que centraron su atención en la iconografía de

\footnotetext{
Jiménez et alii 1985, 274-276.

14 Jiménez et alii 1985, 274.

15 Recuérdese que, además de las memorias de excavación citadas, el hallazgo del mosaico con el Juicio de Paris
} 
la leyenda, mencionando el escaso número de imágenes musivas con este tema en la musivaria romana de todo el Imperio.

En los últimos años, el hallazgo de algunos ejemplos más con esta temática en los pavimentos hispanos ha supuesto de nuevo la consideración del mosaico de Casariche, ${ }^{16}$ si bien al margen del programa decorativo al que pertenecía.

A juzgar por los restos, entre otros, de una cornisa y unos goznes, la entrada a la residencia, las fauces, debía estar en la zona de la zanja sur y, a continuación, una serie de piezas arrasadas que habrían dado paso a un atrio tetrástilo pavimentado por el mosaico del Juicio. ${ }^{17}$ Por las fotografías tomadas en la excavación del mosaico durante la campaña de 1985, cuya disposición aparece también fielmente reflejada en la citada planta de la villa, que fue publicada en el informe de 1986, quien accedía al interior del edificio se encontraba con la representación del Juicio orientada hacia el exterior, de modo que su contemplación habría sido una de las primeras imágenes figuradas, sino la primera, vista al entrar en la pars urbana de la domus.

El mosaico (Fig. 2) estaba bordeado por un filete de 2 hileras de teselas negras (o marrones), una orla de espinas rectilíneas cortas, en oposición de colores, ${ }^{18}$ con la peculiaridad de mostrar cuatro tonos diferentes que van del ocre claro al marrón oscuro sobre blanco, y con la característica de formar una composición de espinas doble en sentido inverso, realmente excepcional en la musivaria romana. A continuación, un filete de cuatro hileras de teselas negras (o marrones), un filete de tres hileras de teselas blancas, un guiloche ancho con centro curvo, en oposición de colores, polícromo, ${ }^{19}$ un filete de tres hileras de blancas - por tanto, el guiloche entre dos filetes de tres hileras de teselas blancas-, un filete de tres hileras de negras, un filete de dos hileras de blancas, un cable con bordes rectos ${ }^{20}$ otro filete de dos hileras de blancas -por tanto, el cable entre dos filetes de dos hileras de teselas blancas-, un filete de dos hileras de negras y, por fin, un filete de una hilera de blancas que rodea ya el campo figurado, sin duda, para adecuarse al espacio disponible.

En el campo de forma cuadrada destaca la escena del Juicio, documentada con certeza en otros dos mosaicos hispanos ${ }^{21}$-el hallado en la villa de Noheda, ${ }^{22}$ de finales del siglo IV, y el descubierto en Castulo, ${ }^{23}$ entre finales del s. II y principios del III-,${ }^{24}$ en un mosaico de Caesarea conservado en el Museo de Cherchel (Argelia), ${ }^{25}$ en un pavimento de Transilvania (Rumanía) ${ }^{26}$ y en otros dos de la parte oriental del

se documenta en Blázquez 1985, 107-124; Buero 1986, 59-60; Balil 1989, 132-145, lám. III, 1; Blázquez et alii 1993, 279-281, fig. 41.

16 López Monteagudo - Neira 2010, 107-109, 133-134; y en particular, a propósito del hallazgo del mosaico de Castulo, López Monteagudo - San Nicolás 2012-2013, 19-25; Blázquez 2014, 109-116; Neira 2015, 61-79; San Nicolás 2015, 558-566; Neira 2018a, 243-244.

17 De la Hoz - Jiménez 1986, 375, fig. 4.

Décor I, pl. 11, d, documentado en Lyon.

Décor I, pl. 74, d, como en Torre de Palma.

Décor I, pl. 6, como en Antioquía.

21 Podrían ser tres, si se considera un fragmento de Caesaraugusta que se conserva en el Museo de Zaragoza con la figura de un varón tocado con un gorro frigio, atribuido a Paris (Neira 2015, 63, n. 2).

Lledó 2010, 129-131; Valero 2013, 307-330.

Cf. nota 15.

Neira 2015, 78-79; 2018, 263.

Albertini 1920; 1921; Ferdi 2005, n 42, lám. XI.

Balil 1989, 138, n. 122; Ciobanu 1995; Lancha 1997, 328. 
Imperio, el de la Casa del Atrio en Antioquía, ${ }^{27}$ de la primera mitad del siglo II, y el hallado en el área de las termas occidentales en la isla de $\operatorname{Cos},{ }^{28}$ entre finales del siglo II y principios del III.

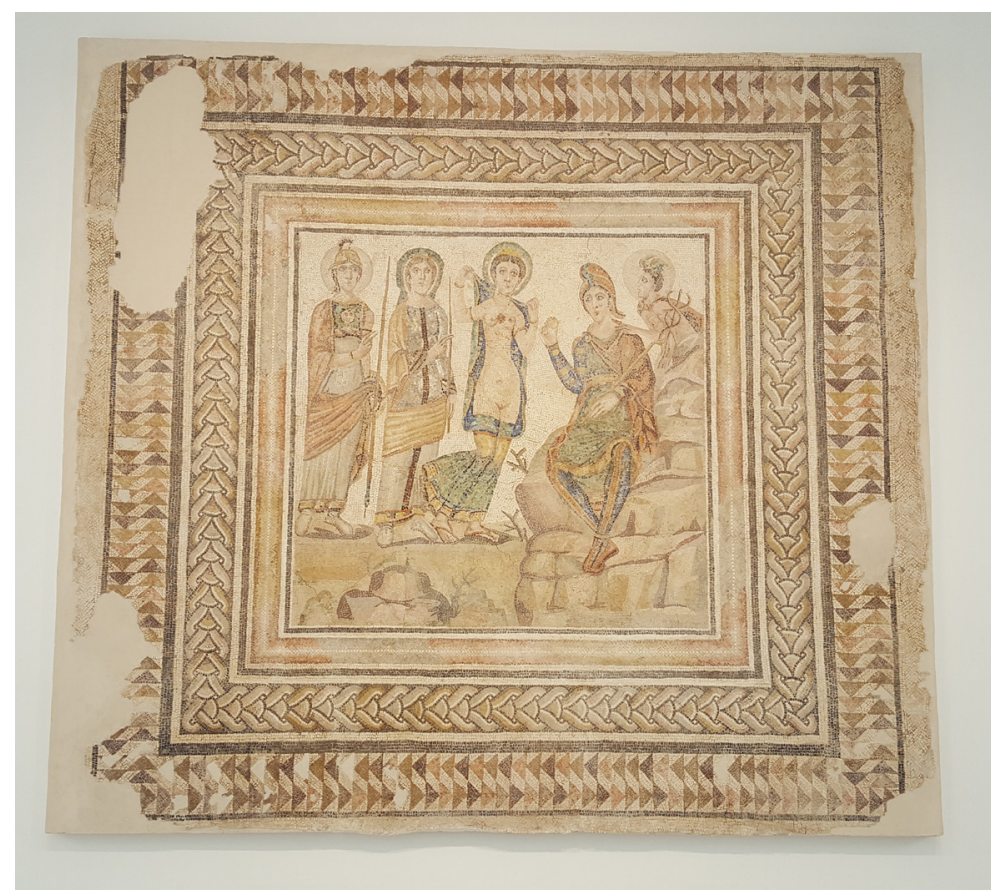

Fig. 2. Mosaico del Juicio de Paris, "El Alcaparral” (Fotografía: Luz Neira)

En el mosaico de Casariche, Hermes aparece detrás de Paris, quien está sentado sobre una roca que evoca el monte Ida, frente a las tres diosas para efectuar el Juicio, como en el mosaico de Antioquía, lo que, a pesar de la laguna en la parte izquierda de la escena del Juicio en Noheda, ha servido de base para identificar las piernas del personaje sentado como Paris, a cuyos pies figura un eros, y a plantear asimismo la presencia, en origen, de Hermes a su espalda, tal y como aparece en el citado pavimento de Casariche, pero a la inversa, y en otras representaciones de la leyenda, ${ }^{29}$ si bien en Noheda la representación del Juicio, no obstante, forma parte de un gran panel rectangular en el que, de izquierda a derecha, figuran además las escenas del embarque de una joven pareja identificada como la huida de Helena y Paris, su llegada a Troya y el festivo recibimiento, componiendo una imagen única en la musivaria romana.

En lo que concierne a la escena del Juicio en los tres mosaicos citados, aun con las diferencias que supone, por un lado, su inserción en un relato más extenso de episodios en el pavimento de Noheda y, por otro, la inclusión de detalles escenográficos más precisos en Antioquía, con la representación del ganado, que como pastor Paris 
apacentaba, la figura de un eros y la de Psique, ${ }^{30}$ se aprecia el reflejo de dos secuencias en una sola al haber conjugado en el mismo plano por un lado el mensaje de Hermes -con la decisión de Zeus- al joven pastor, aún ignorante de su auténtico origen, como el mortal designado para elegir a la ganadora del concurso y, por otro lado, tras aquella orden, la elección de Paris propiamente en su calidad de juez. Bien es cierto que en el mosaico de Antioquía se destaca de modo más nítido el mensaje de Hermes a Paris, quien incluso aparece volviendo su cabeza hacia el dios, con las tres diosas, completamente vestidas, expectantes, mientras que en Casariche la conjunción de ambas secuencias alcanza su máxima expresión al mostrar tanto el instante del mensaje de Hermes a Paris como la resolución del joven juez, con el ansiado trofeo de la manzana en su mano derecha alzada para Afrodita, en una actitud ciertamente triunfante y mostrando su cuerpo al desnudo en contraste con sus dos rivales, tal y como se documenta también en la escena conservada en Noheda.

En el mosaico hallado en las proximidades de las termas del Este en la antigua Caesarea $(\text { Cherchel) })^{31}$ (Fig. 3), muy afectado por grandes lagunas, Paris se encuentra igualmente sentado de tres cuartos en el extremo derecho del campo rectangular, pero contemplando la llegada de Hermes, quien, frente a él en este pavimento, precede a las tres diosas: Atenea, de la que todavía se aprecia el gran escudo, Afrodita, de la que se conservan las piernas al desnudo, y Hera, bien cubierta, en el extremo izquierdo. Este tipo de escena recuerda a aquellas documentadas en la pintura de algunos vasos de época clásica, donde se plasma la llegada de Hermes y las diosas en comitiva a presencia de Paris.
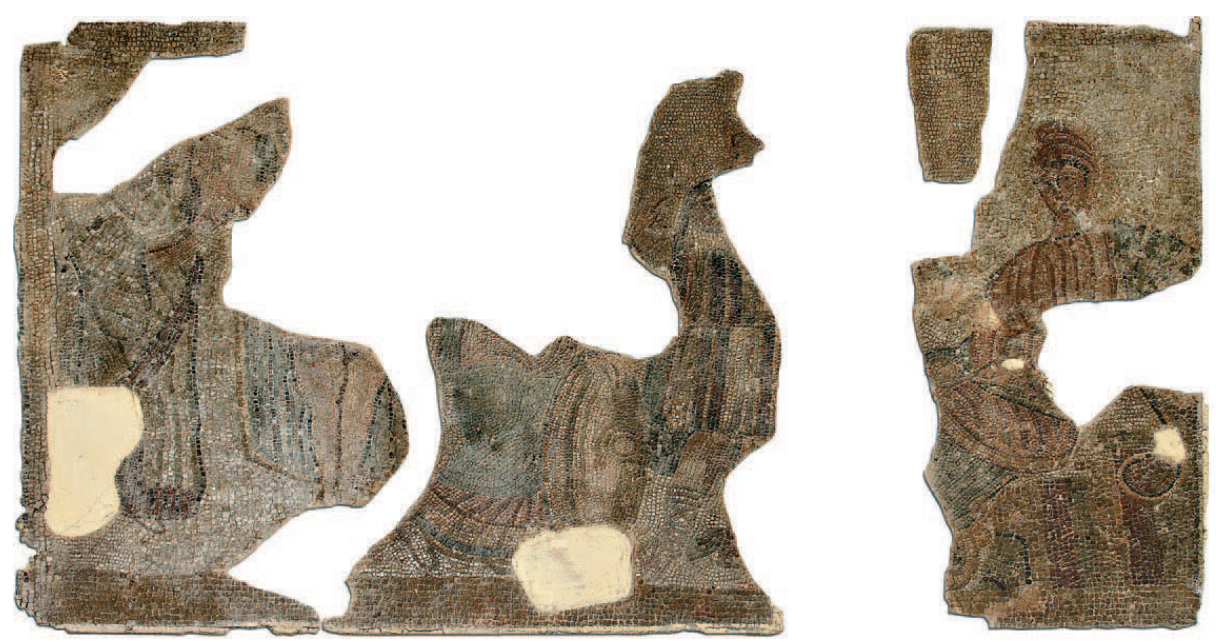

Fig. 3. Mosaico del Juicio de Paris, Caesarea, Museo de Cherchel (cortesía de S. Ferdi)

Una imagen similar aparecía en el mosaico hallado en la provincia romana de Dacia, en la zona de Transilvania (Rumanía), ${ }^{32}$ donde, a juzgar por el dibujo que

Balil 1989, 137.

Ferdi 2005, 58-59, nº 42, lám. XI.

32 Hallado en 1823, no fue publicado hasta 1851 y reproducido en Reinach 1922, 164, 1, si bien el estudio y el dibujo más preciso es el de Berciu en 1961, a juicio de Balil 1989, 138, n. 122, quien se hacía eco de que este mosaico apareció con otro donde estaba representado Príamo, postrado a los pies de Aquiles, suplicando la 
se conserva, Paris también se encontraba sentado en el extremo derecho del panel, mientras Hermes, de pie junto a él, parece presentarle a las diosas participantes en el concurso de belleza, Atenea, Hera y Afrodita, por este orden, de modo muy semejante a la escena representada en una pintura pompeyana o fresco de Herculano. ${ }^{33}$

La presentación de las diosas por parte de Hermes a Paris está representada de forma aún más nítida en el interesantísimo mosaico de $\operatorname{Cos}^{34}$ (Fig. 4), donde, a pesar también de las considerables lagunas, todavía se puede apreciar en el extremo izquierdo del campo rectangular la figura del joven pastor, sentado, de perfil, sobre una roca, al pie de un árbol en cuyo tronco se posa un águila, provisto del característico pedum y en compañía de un bóvido, indicativo del rebaño que apacentaba, quien parece muy atento a Hermes, situado de pie junto a él, prácticamente desnudo, en una actitud inequívoca que refleja el instante en el que se encuentra presentando a las diosas, a las que precede e incluso señala con su mano para atraer la atención de Paris.

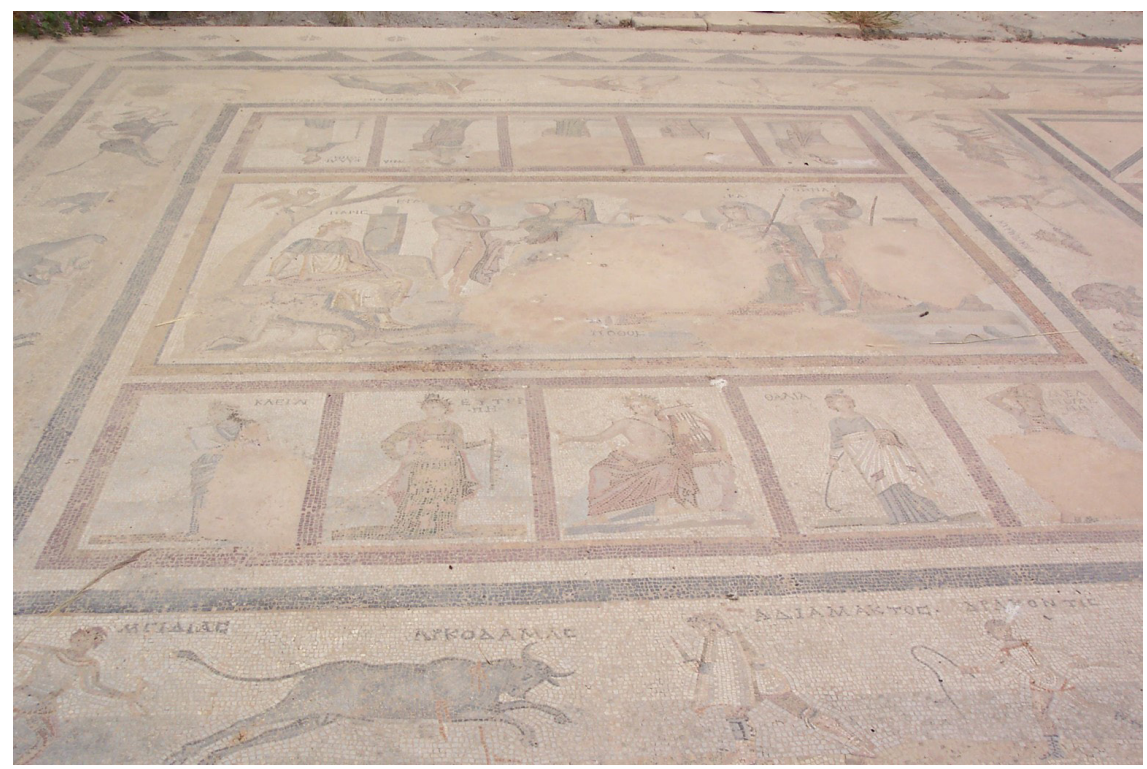

Fig. 4. Mosaico del Juicio de Paris, Cos (De Matteis 1999, 67)

devolución del cadáver de su hijo Héctor, un episodio documentado en pintura de vasos y en orfebrería, aunque desconocido en otros pavimentos romanos.

33 Reinach 1922, 164, 2.

34 De Matteis 1999, 59-67, el tapiz con la escena del Juicio muestra en el lado superior e inferior cinco recuadros, diez en total, con la representación de Apolo y las nueve Musas. Además, el mosaico presenta una orla figurada, que a modo de friso rodea los cuatro lados, con escenas de las venationes que se celebraban en el anfiteatro, de cara al exterior. Dicha orla con los protagonistas de las venationes bordea asimismo los otros dos tapices, muy destruidos, convirtiéndose, por tanto, en el elemento que unifica los tres tapices (De Matteis 2004, 33-53, tavv. II-XIII). A este respecto, el pavimento muestra el mismo esquema en los dos tapices laterales, de modo que, a pesar del deterioro, un tapiz idéntico al del Juicio, con campo central y cinco recuadros en el lado superior y otros cinco en el inferior, se documenta en el extremo oriental, mientras el central, con figuras fragmentarias de asunto báquico, probablemente el triunfo de Dioniso en el círculo central, y la lucha entre Eros y Pan, presenta una composición similar al esquema a compás, pero según una variante que en los ángulos, en lugar de cuartos de círculo, reproduce triángulos (De Matteis 2004, 360, tav. B). 
Las enormes lagunas que se ciernen sobre el pavimento no nos impiden atisbar por este orden a una pequeña figura que parece estar sentada sobre una roca, portando un espejo, acaso Peitho ${ }^{35}$ y a otra, en la parte inferior, prácticamente perdida, identificada por una inscripción con el nombre de $\Pi O \Theta O \Sigma$, que, a juzgar por sus pies, debía estar de espaldas al espectador y de frente a la diosa Afrodita, muy dañada, salvo el busto, el brazo derecho y la parte anterior del pie, quien parece estar de pie, desnuda y mesándose los cabellos, y, a continuación, Hera, con certeza sentada sobre un noble asiento, similar a un trono, aunque la escena transcurriera al aire libre en el monte Ida, según la leyenda, y, en este sentido, en un escenario campestre y pastoril, bien explícito en esta representación musiva, y Atenea, de pie, apoyándose con su codo en el trono de Hera y con la mano en el mentón en actitud ciertamente pensativa, junto a una estela situada en el extremo derecho del tapiz. Además, la escena del Juicio en Cos muestra nimbadas tanto la figura de Hermes como las de las diosas -al menos Hera y Atenea, probablemente también Afrodita, si bien la laguna nos impide confirmar este detalle-, igual que en el pavimento de Casariche, como nota distintiva en ambos mosaicos, ya que en el resto las cuatro divinidades aparecen representadas solo con sus características habituales, sean las alitas sobresaliendo de los cabellos en el caso del dios, una rica diadema, el velo sobre la cabeza y el casco, que tampoco faltan en Cos y Casariche. No obstante, es preciso destacar como excepcional en el pavimento de Cos los epígrafes musivos en griego que se documentan en las escenas de venatio e identifican también con su nombre propio a las nueve Musas, no así a Apolo, y a los personajes mencionados que forman parte de la representación del Juicio, es decir, Paris, Hermes, Pothos, ${ }^{36}$ Afrodita, Hera y Atenea. ${ }^{37}$ Por todo lo señalado, la escena del mosaico de Cos es realmente excepcional en la musivaria, aunque tiene sus paralelos más próximos en una pintura pompeyana de la domus VII, 2, 14 sobre la vía a Stabiae y en una copa vítrea pintada, atribuida al sur de Siria, ${ }^{38}$ en esta última con la presencia también de Pothos, representado, sin embargo, en vuelo cerca de Afrodita.

Sobre Pothos, es preciso resaltar que su representación junto a Afrodita está bien documentada en la pintura de vasos áticos ${ }^{39} \mathrm{y}$ también apulios, como aquel de figuras rojas, fechado en torno al 360 a.C., donde ambos, identificados por inscripciones como el resto de los personajes, han sido incluidos en la representación de la llegada

35 De Matteis 2004, 43, 50, para quien Peitho, personificación de la fuerza de la persuasión, "è compagna delle Muse per la caratterizzazione dell'amore in senso morale, regolando sia le relazioni affettive sia quelle concernenti la vita associata più in generale".

36 Sobre la representación de Pothos en escenas del Juicio de Paris, Kossatz-Deismann 1994.

37 La conjunción de estas escenas sin conexión aparente, fue interpretada por Kondoleon 1995, 308-309, como probable representación de un muпus ofrecido por el comanditario del mosaico, quien habría así recordado su evergetismo, máxime si se considera a través de los nombres de los protagonistas de las venationes el interés por reflejar no un munus más, sino aquel en el que participaron los venatores, incluso las fieras, identificados con su nombre propio, mientras la escena del Juicio de Paris podría ser, a tenor de la referencia de Apuleyo (Apul. Met. 10.29-33), la representación de un espectáculo público, un munus en Corinto, igual que las Musas. Efectivamente, sobre el objetivo de personalizar las escenas de venatio no me cabe duda, según lo planteado por Kondoleon, si bien el problema a la hora de relacionar las demás imágenes y su significado por el deterioro de las otras dos representaciones impide llegar a conclusiones más firmes, particularmente si se considera que las escenas de venatio eran las que daban cohesión a los tres tapices, tal y como ya apuntaba De Matteis 2004, 178, n. 699 .

38 De Matteis 2004, 43.

39 Bazant 1994, 501-503. 
de Pélope a la corte de Enómao en presencia de Hippodameia. ${ }^{40}$ No es de extrañar, recuérdese a este respecto que Pothos es mencionado como el hijo de Afrodita y un miembro de su cortejo por Esquilo, ${ }^{41}$ aunque también como hijo de Eros por Platón ${ }^{42}$ y Eurípides, ${ }^{43}$ quien, no obstante, también se refiere a Pothos en otra de sus obras ${ }^{44}$ en el reino de Dioniso.

En contraste con el pavimento de Cos, la representación de Pothos en otros mosaicos parece responder a una significación diferente, tal y como hemos puesto ya de manifiesto, ${ }^{45}$ más en sintonía con la vision de Sófocles, ${ }^{46}$ el primer autor que lo describe como personificación del amor por alguien ausente, línea seguida por Platón en su Crátilo, quien aclaraba el significado de algunos erotes, que, excepcionalmente identificados con un nombre propio, están representados en pinturas de vasos:

Se llama pesar (potos), para mostrar que no se refiere a nada presente, sino a un objeto que está en otra parte y lejos de nuestro alcance (alloti pou ortos kai apontos). De donde resulta que se nombra (potos) lo que se llamaba (imeros) cuando el objeto deseado estaba presente..$^{47}$

El significado dado por Sófocles y Platón sobre Pothos, como personificación del deseo amoroso por alguien que, estando ausente, no puede ser satisfecho, causando dolor, sufrimiento y anhelo, es asimismo mencionado por Plinio, ${ }^{48}$ y explicaría, más allá de la vinculación a Afrodita, su inserción en la escenificación de otras leyendas mitológicas diferentes. Recuérdese la representación de Pothos en un mosaico, por desgracia, de procedencia, contexto y paradero actual desconocidos, ${ }^{49}$ que había aparecido en el mercado de antigüedades de Londres en 1979 y había formado parte de una colección privada de California hasta los años noventa, saliendo a subasta en Christie's de Nueva York el 10 de junio de 2010, según la breve información del catálogo. ${ }^{50}$ A pesar de su conocida iconografía, dos inscripciones en griego con los nombres de EN $\triangle \mathrm{YMI} \Omega \mathrm{N}$ y $\Sigma \mathrm{E} \Lambda \mathrm{HNH}$ identificaban al joven durmiente y a la bella Selene, con su característico creciente lunar, en una biga, de la que sólo se aprecia el borde de la caja curva y una rueda de ocho radios, tirada por dos toros que avanzan hacia la derecha, bien documentados en otras imágenes de Selene. ${ }^{51}$ En una posición complicada, con las rodillas flexionadas, la diosa parece estar representada en actitud de descender del carro, aunque no se aprecia bien si lo ha hecho o figura de pie ya

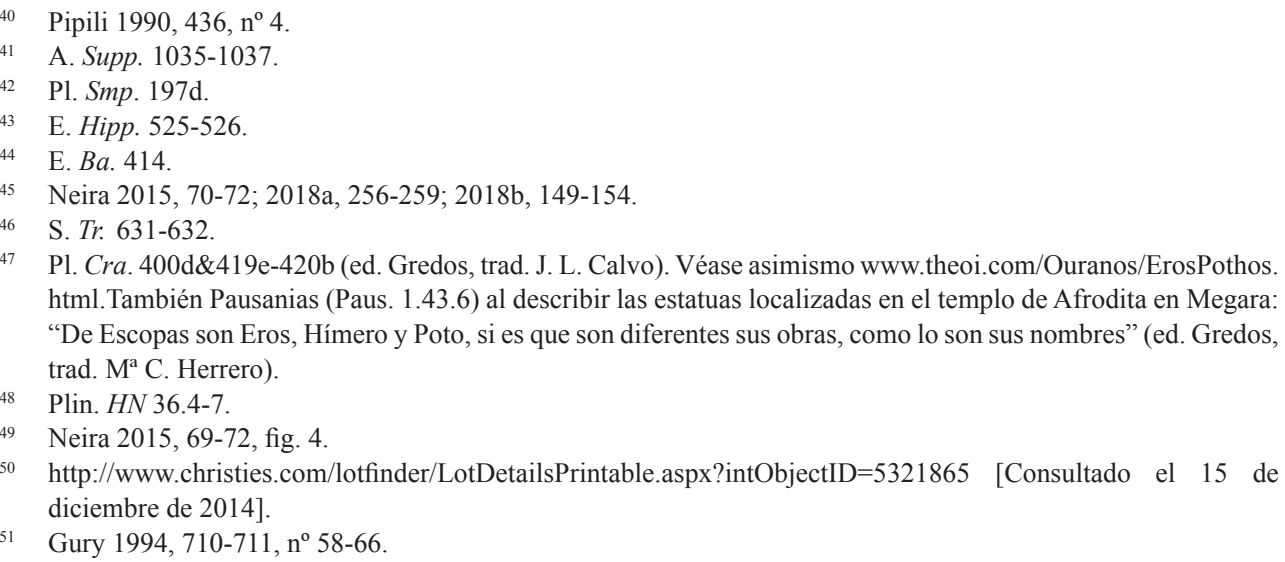


en tierra, pero, en lugar de dedicar su mirada a Endimión, Selene dirige sus ojos y una gran antorcha encendida hacia un eros alado y desnudo, situado en la parte superior derecha de la imagen, cuyo índice señalando al joven durmiente intenta captar la atención de la diosa. No sería de extrañar, si se tiene en cuenta la presencia de un eros en el mosaico ostiense de Isola Sacra y en el de Nîmes, así como en varias escenas documentadas, entre otras, en pinturas y sarcófagos, ${ }^{52}$ excepto que este eros es identificado, como los protagonistas, por una inscripción en griego con el nombre de $\Pi \mathrm{O} \Theta \mathrm{O} \Sigma$. Evidentemente, en el mosaico a subasta en Christie's, el eros señala con su dedo al durmiente Endimión, que por la eternidad de su profundo sueño, y a pesar de los deseos amorosos de la diosa, hace inviable la unión, causando en Selene el anhelo, la nostalgia y el dolor sentido por un amor "ausente", en la línea señalada por varios de los autores antiguos antes citados. ${ }^{53}$

La figura de otro eros, también identificado por una inscripción en griego con el nombre de $\Pi \mathrm{O} \Theta \mathrm{O} \Sigma$, se documenta asimismo en el mosaico de las Bodas de Dioniso y Ariadna encontrado en Philippopolis ${ }^{54}$ que, datado en el segundo cuarto del siglo IV, se conservaba en el Museo de Shahba. ${ }^{55}$ Pero aquí, en vez de personificar el amor por un ausente, en tanto durmiente e inconsciente e incapaz de corresponder y, por tanto, el anhelo, el sufrimiento y el dolor, Pothos se encuentra entre la pareja, portando una antorcha llameante que suele simbolizar el himeneo, la unión amorosa, de modo acorde a la narración de la leyenda sobre las nupcias, lo que indujo a preguntarnos por el sentido de la incorporación de Pothos en esta escena. Podría aducirse la mención dada por Eurípides, quien en su Hipólito ${ }^{56}$ se refiere a Pothos como hijo de Eros mientras en otra de sus obras ${ }^{57}$ lo sitúa en el reino de Dioniso, ${ }^{58}$ no obstante la referencia más reveladora se encuentra en un pasaje de Nonno, ${ }^{59}$ cuando el autor de Panópolis, al abordar las bodas de Dioniso y Ariadna, describe que la previa experiencia de amor anhelado y no logrado con Teseo sumió en un gran dolor a Ariadna, pero que fue este amor no consumado, Pothos, el que posibilitó finalmente la unión con Dioniso: "[Dionysos se dirige a su futura esposa Ariadna:] No por nada hizo eso que la nave [de Theseus] zarpara de Naxos [abandono de Ariadna en la isla], pero Pothos (deseo sexual) te preservó para un nupcial más noble". ${ }^{60}$

En este mismo sentido, hemos interpretado la presencia de $\Pi \mathrm{O} \Theta \mathrm{O} \Sigma$ en el ejemplar de Bagot, ${ }^{61}$ donde Pothos estaría representando el amor anhelado de Hipodamía

\footnotetext{
Gabelmann 1986, 731, nº 29, 5.

53 Salvo en Propercio (Prop. Eleg. 2.15.13-24), donde de modo explícito se afirma lo contrario "Desnudo dicen que Endimión cautivó a la hermana de Febo, y que se acostó con la diosa desnuda” (ed. Gredos, trad. A. Ramírez de Verger).

54 Neira 2015, 71-72, fig. 5.

55 Balty 1977, 50-56.

E. Hypp. 525-526.

E. Ba. 414.

Neira 2015, 71, fig. 5.

Nonn. D. 47.442.15.

60 En otro pasaje Nonno afirma que Pothos es un hijo de Zephyros e Iris (Nonn. D. 25.150; 31.103); mientras, en contraste, más adelante: (Aglaia llama a Eros para asistir a su madre Afrodita) “¡Apresúrate! Kythereia [Afrodita] está en apuros. Ninguno de sus asistentes ha permanecido con ella; Kharis (Charis, Gracia) se ha ido, Peitho (Seducción) ha desaparecido, Pothos (Deseo Sexual) el inconstante la ha dejado; No tenía más que enviarme a mí. ¡Ella necesita tu invencible carcaj!” (Nonn. D. 33.112; ed. Gredos, trad. D. Hernández de la Fuente).

${ }^{61} \quad$ Neira 2018b, 154, fig. 1.
} 
hacia cada uno de los muchos pretendientes eliminados sistemáticamente por su padre, hasta el punto de que la joven habría temido no poder cumplir su sueño de contraer matrimonio; pero, como en el mosaico sirio de Philippopolis, sería esta experiencia previa -de amor anhelado y no logrado, en definitiva, de Pothos-la que, en la línea de Nonno sobre Ariadna, finalmente posibilitaría su unión con Pélope. Por esta razón, es Pothos, todavía con la antorcha llameante al hombro, quien señala hacia el edificio donde debe dirimirse la célebre carrera, indicando el modo de llegar a esa unión, mientras la joven Hipodamía, sentada, pero animada por la intervención de Pothos, alza la palma destinada a los vencedores ante la presencia de Pélope, en actitud de indicarle la acción que el joven pretendiente debería realizar para lograr su amor, la hazaña del triunfo sobre Enómao en la carrera de cuadrigas.

Por tanto, el simbolismo de Pothos en los tres mosaicos citados difiere a nuestro juicio del Pothos estrechamente vinculado a Afrodita que, en este sentido, se documenta de modo único en el pavimento de Cos, cuya escena sigue aquella tradición más antigua, antes citada, según la cual, a juzgar por su filiación, aparece junto a Afrodita en pinturas de vasos y vidrios, acompañando a la diosa en diferentes representaciones, entre las que se cuenta la del Juicio de Paris.

Volviendo a la escenificación del Juicio en la musivaria romana, es preciso resaltar que, además de las secuencias representadas en Casariche, Antioquía y Noheda y las plasmadas en Caesarea, Transilvania y Cos, el descubrimiento en 2015 del denominado mosaico de los Amores en Castulo nos ofrece un tercer tipo de escena, ${ }^{62}$ en un novedoso esquema compositivo, similar al "esquema a compás", si bien como particularidad muestra seis semicírculos laterales sobre los lados y dos círculos centrales, dando como resultado seis cuadrados de lados curvos en los espacios restantes ${ }^{63}$ probablemente en referencia a la adaptación de un esquema determinado a la superficie por pavimentar y decorar. A este respecto, si el esquema compositivo resulta inusual, tampoco la iconografía de las escenas principales es la más frecuente, aquella que reproduce en cierto modo el esquema de muchas de las pinturas de vasos griegos de época arcaica y clásica y de célebres pinturas pompeyanas, como la de la Casa del Citarista, ${ }^{64}$ una disposición lineal con las cinco figuras protagonistas de la leyenda en el mismo plano, donde destaca la elección de Paris, el denominado Juicio. Como novedad, la escena representada en el pavimento de Castulo (Fig. 5) resalta y prima la secuencia previa al Juicio, el instante mismo en el que Hermes, por orden expresa de su padre, ha acudido a presencia del joven pastor Paris en el monte Ida para encomendarle que ejerza de juez árbitro en el concurso de belleza entre Atenea, Hera y Afrodita, haciéndole entrega del premio a otorgar a la diosa que resultara triunfadora, la denominada manzana de la discordia -donde podía leerse entréguese

62 Neira 2015, 61-79, con un análisis de todas las fuentes literarias acerca de las leyendas representadas en el mosaico, que, ante la inusual conjunción del Juicio de Paris y los amores de Selene y Endimión, pudiera explicar la peculiar iconografía y su interrelación en el denominado mosaico de los "Amores", sin olvidar el análisis de los motivos geométricos del pavimento en el que se sitúa el esquema compositivo, con las citadas escenas figuradas, pues su datación, siempre que fuera factible, contribuiría a arrojar luz sobre la cronología del mosaico y su contexto.

63 En los semicírculos laterales se encuentran las figuras de erotes cazadores y en los seis cuadrados de lados curvos sendas figuras de animales, mientras en los sí habituales cuartos de círculo aparecen los bustos de las Estaciones. Véase sobre este esquema y los erotes, López Monteagudo - San Nicolás 2012-2013, 19-25; López Monteagudo 2014, 117-126; San Nicolás 2018, 194-195.

64 Kossatz-Deissmann 1994, 176-188. 
a la más bella- lanzada por Eris, la personificación de la venganza, al verse ultrajada por no haber sido invitada a las bodas de Tetis y Peleo, mientras las tres diosas, en la zona superior del espacio circular, en lugar de haber sido captadas en el momento de la elección con la consiguiente entrega de la manzana a Afrodita, aguardan expectantes a una prudente distancia.

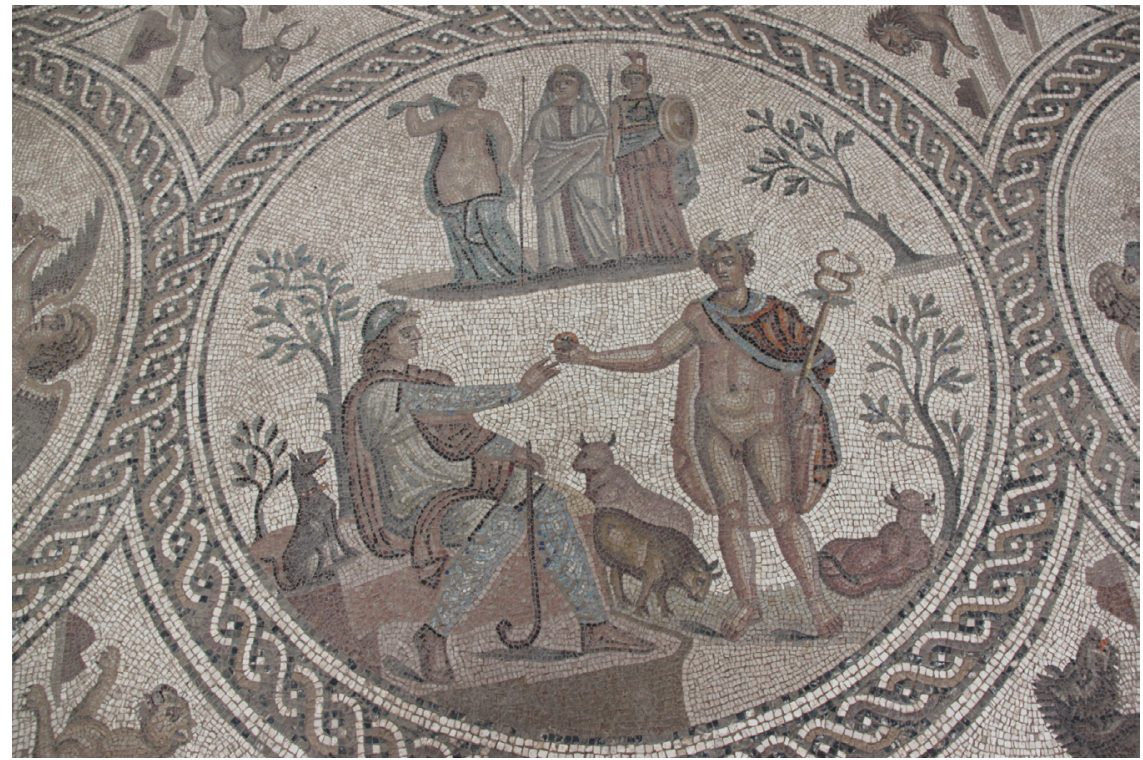

Fig. 5. Mosaico de Castulo; detalle de la escena del Juicio (Fotografía: Luz Neira)

Como ya se señaló, ${ }^{65}$ la imagen más próxima a la escena representada en Castulo se encuentra en una moneda de Antonino Pío de Alejandría, fechada en los años $141 / 142-142 / 143,{ }^{66}$ con las tres divinidades en la parte superior y Paris y Hermes en la inferior, pero a la izquierda, si bien esta similitud reside más en la forma circular en la que se inscribe y en la disposición de las diosas que en las figuras de Paris y Hermes, común a las de otras representaciones, incluso en mosaicos. A este respecto, nos preguntábamos hasta qué punto la particular representación del Juicio de Paris en el mosaico de Castulo podría entonces responder a una versión concreta de las numerosas referencias contenidas sobre el tema en diversas obras de la época griega, tales como la Iliada ${ }^{67}$ las Ciprias,${ }^{68}$ algunas tragedias perdidas de Sófocles y otras de

\footnotetext{
Neira 2015, 64-68.

Kossatz-Deissmann 1994, 186, nº 94.

Hom. Il. 24.22-30.

8 Recuérdese que esta obra, fechada entre los siglos VIII-VII a.C., pero desgraciadamente perdida, se conoce por un resumen muy posterior del gramático Proclo en su Crestomatía del siglo II d.C., objeto a su vez de un resumen en la Biblioteca de Focio en el s. IX d.C., donde se narraba la inesperada aparición en la boda de Tetis y Peleo de Eris, quien, al sentirse ultrajada por no haber sido invitada, habría ofrecido ante todos los presentes la manzana de oro para la más bella, dando lugar a la consiguiente presentación de las candidaturas de las tres diosas, un asunto extremadamente delicado que Zeus habría eludido ordenando a su hijo Hermes comunicara a Paris su designación como juez en el concurso de belleza, dando origen al conocido episodio. En otro resumen de las Ciprias a cargo de Apolodoro se documenta las promesas de las tres diosas a Paris, con la clara intención de influir en la decisión de aquel joven pastor (Apollod. Epit. 3.2).
} 
Eurípides, ${ }^{69}$ y, ya de época romana, las Heroidas de Ovidio, las Fábulas de Higinio, la Biblioteca de Apolodoro, algunas obras de Luciano de Samósata, la Descripción de Grecia de Pausanias y las Metamorfosis de Apuleyo, siendo estas últimas, y en particular, la de Ovidio y las de autores del s. $\mathrm{II}^{70}$ como Apuleyo ${ }^{71}$ y Luciano, ${ }^{72}$ las que ofrecen mayor conexión con la escena figurada en el pavimento de Castulo.

A este respecto, el testimonio más revelador es el de Apuleyo, un extenso relato de una representación teatral presenciada por Lucio, con la recreación, entre otros, del episodio del Juicio de Paris, que alude a la adaptación e incorporación de mitos y leyendas de origen griego en las escenificaciones teatrales durante el Imperio romano. De particular interés para la representación en el mosaico de Castulo, en concreto para las figuras de Hermes y Paris, es el siguiente pasaje:

Era una montaña de madera que recordaba el célebre monte Ida (...) se habían plantado en él enramadas y verdaderos árboles (...); un joven representaba al pastor frigio Paris: llevaba una hermosa túnica y manto oriental colgando a su espalda con abundante vuelo; (...) y hacía como que guardaba el ganado. De pronto aparece un jovencito muy llamativo, desnudo, o, mejor dicho, con una clámide de efebo que sólo le cubría el hombro izquierdo; su rubia cabellera atraía todas las miradas, y de entre sus rizos sobresalían unas alitas de oro dispuestas con perfecta simetría; su varita permite reconocer en él a Mercurio. Se adelanta bailando, con una manzana de oro en la mano derecha, y la entrega al joven que hacía el papel de Paris; le da a entender por señas el mensaje de Júpiter y, retirándose en seguida con gracioso ademán, desaparece. ${ }^{73}$

Reflejando, aunque fuera desde el ámbito de la ficción, el auge de las artes escénicas más en boga en el Imperio romano, la descripción en la obra de Apuleyo del mimo que pudo contemplar Lucio en Corinto refería, por tanto, la llegada primero de Hermes a presencia de Paris, la entrega de la manzana de oro como trofeo para la vencedora, la transmisión del mensaje por señas y su marcha, y a continuación, solo tras su salida de la escena, la aparición, por turnos, de las diosas, primero la joven que representaba el papel de Juno, después la que encarnaba a Minerva y, por último, la que figuraba como Venus, y no las tres al tiempo, como suelen ser representadas, si bien ya Balil ${ }^{74}$ aludía a la imposibilidad de plasmar las diferentes secuencias del mimo y, por tanto, a la necesidad de elegir una instántanea, representativa, en respuesta a la transmisión de la Cultura Escrita a la Cultura Visual. Y en este sentido, el Juicio de Paris en Castulo refleja el instante preciso en el que Hermes le entrega la manzana a Paris, sin intercambiar palabra alguna, mientras las tres diosas al haber salido a escena han sido captadas expectantes ante la decisión de Paris, como un episodio previo al mismo Juicio.

69 Donde se reflexionaba sobre la responsabilidad de quiénes, siguiendo las directrices de las divinidades, decidían y ejecutaban finalmente sus deseos, sin obviar por tanto su correspondiente culpa.

70 Higinio (Hyg. Fab. 92) refería el Juicio, deteniéndose más en las promesas que cada una de las diosas hizo al joven pastor y la sentencia final, en la misma línea, pero de modo más resumido, que Apolodoro (Apollod. Epit. 3.2) y Pausanias (Paus. 5.19.5).

71 Apul. Met. 10.30-34.

72 Luc. DIud. 1; DDeor. 7-9.

73 Apul. Met. 10.30.1-5 (ed. Gredos, trad. L. Rubio).

74 Balil 1989, 137. 
Una escenificación diferente a la documentada en Casariche, Antioquía, probablemente en Noheda, y también en Caesarea, Transilvania y Cos, donde, con independencia de la posición de Hermes, a espaldas o frente a Paris, el dios mensajero no solo se dirige a Paris, sino que le revela al oído o en voz alta la misión que Zeus le ha encomendado. En esta línea, la representación en estos mosaicos responde más a las referencias transmitidas por Ovidio y Luciano.

Recuérdese que Ovidio, en una de sus Cartas, hace referencia al impacto que causó en el joven pastor -quien se expresa en primera persona- la presencia de Hermes guiando a las diosas y el encargo que este le da en nombre de Zeus:

Pastor no temas, me dijo el dios al verme sorprendido, y hablando continuó, de esta manera:

"Árbitro vas a ser de la hermosura; dirime de estas diosas la contienda, y pronuncia aquí mismo, cual de todas de más hermosa el galardón merezca". Y añadió, porque yo no me excusara, "el soberano Jove lo decreta" dijo, y batiendo las ligeras alas alzóse al éter y al Olimpo vuela. ${ }^{75}$

También son reveladores algunos diálogos de Luciano:

¡Hermes!, toma esta manzana y vete a Frigia a casa del hijo de Príamo. El pastor de bueyes, que apacienta las manadas en el Gárgaro, en las estribaciones del Ida, y dile: "A ti, Paris, puesto que eres hermoso y entendido en temas del amor, te encarga Zeus juzgar a las diosas, a ver, cuál de ellas es la más hermosa. La que resulte vencedora obtendrá la manzana como premio del concurso. ${ }^{76}$

Y en particular al "reproducir" la conversación que el dios mensajero habría mantenido con un sorprendido Paris:

Pero ¿por qué tiemblas y palideces? No temas: no hay ningún mal. Él ordena que tú seas el juez de la belleza de ellas y te dice: - Porque tú eres bello, y sabes todas, en profundidad, las cosas de amor, yo confío a ti este juicio. Sabrás el premio de esta lucha, leyendo lo que está escrito sobre esta manzana.

Paris: - Dámela, voy a leerla, dice: "La bella la tenga". ${ }^{77}$

Se trata de textos que, a diferencia de otros testimonios literarios donde se da primacía a las causas de la discordia o a las promesas de las candidatas divinas, destacan el mensaje, oral, de Hermes y la presentación de las candidatas, si bien en el mosaico de Casariche se ha incorporado también el instante de la elección final, ${ }^{78}$

Ov. Ep. 16.51 (ed. Alianza, trad. V. Cristóbal).

Luc. DIud. 1 (ed. Gredos, trad. J. L. Navarro).

Luc. DDeor. 7-9 (ed. Gredos, trad. J. L. Navarro).

Es posible que también en la escena representada en Noheda, a juzgar por la actitud de Afrodita, quien, figurando 
ya que, como se ha señalado anteriormente, Paris sostiene en su mano derecha alzada la codiciada manzana, que, sin titubear, acerca a Afrodita, que se muestra orgullosa con el cuerpo al desnudo, a pesar de los vanos intentos de Hera y Atenea que habían intentado neutralizar la elección de su contrincante señalándole con un claro signo apotropaico con dos de los dedos de su mano derecha. En suma, una representación única en la musivaria romana.

Desde esta estancia pavimentada con el mosaico del Juicio de Paris, se accede a la habitación numerada con el $n^{\circ} 3$ en la planta publicada tras la segunda campaña de excavaciones en "El Alcaparral". 79

El pavimento está bordeado por una línea de semicírculos secantes y tangentes formando ojivas y escamas, en oposición de colores negro y blanco,${ }^{80}$ que enmarca una composición ortogonal de círculos secantes (dejando entrever cuadripétalos y formando cuadrados cóncavos) con cuadrado pequeño sobre la punta inscrito en los husos, ${ }^{81}$ los cuadripétalos rellenos de teselas rojas, documentado también en uno de los tapices de la denominada villa suburbana de Mitra. ${ }^{82}$

A juzgar por las excavaciones realizadas, desde esta sala se debía acceder a la estancia $\mathrm{n}^{\mathrm{o}} 4$, identificada como un cubiculum, y con seguridad a la estancia $\mathrm{n}^{\mathrm{o}} 5$.

El pavimento $\mathrm{n}^{\mathrm{o}} 4$ se encontró ya en muy mal estado y había sido objeto de restauración en la Antigüedad. Muy deteriorado, presenta una onda de peltas negras con triángulo dentellado en el apéndice, ${ }^{83}$ con peltas iguales a las representadas en el campo del mosaico $\mathrm{n}^{\circ} 11$, pero la composición geométrica apenas es perceptible.

El fragmentario mosaico $n^{\circ} 5$ (Fig. 6), que se encuentra expuesto en la Colección Museográfica del Mosaico de Casariche, pavimentaba en origen una habitación identificada por sus excavadores como un oecus, al que, según se ha indicado, se accedía desde la estancia $n^{0} 3$. Tal y como aparece en el plano general del edificio con los pavimentos y lagunas que estos presentaban en el momento de su descubrimiento, ${ }^{84}$ no como figura en la reconstitución de la maqueta, uno se encuentra con un panel rectangular bícromo, decorado con doble hilera de hexágonos regulares adyacentes, dispuestos sobre la punta y silueteados en negro sobre blanco, con un cuadrado dispuesto sobre la punta en el centro, formado a base de un ajedrezado blanquinegro, dejando triángulos isósceles en ambos bordes superior e inferior. En el lado opuesto a la entrada a la estancia, otro panel con una línea de cuadrados escuadrados, delineados en negro sobre blanco, unidos por cuatro líneas, en cuyo centro figura una florecilla en cruz, en aspa. Como orla de enmarque que rodea todo el campo, un follaje de acanto igualmente en negro sobre blanco, con la particularidad de que aparece unido por dos líneas en la parte superior y en la inferior de las hojas de

la más próxima a Paris, muestra su cuerpo asimismo al desnudo, y en particular por la posición y el rostro de Atenea, con un gesto que podría interpretarse entre la decepción y la amargura. No obstante, la laguna que afecta al extremo izquierdo del panel nos impide confirmar si Paris portaba en su mano la manzana, con un ademán de entregarla a Afrodita.

79 De la Hoz - Jiménez 1986, 373-379, fig. 4.

80 Décor I, pl. 49, a, como en Volubilis.

81 Décor I, pl. 239, d, como en un mosaico galo.

82 Jiménez - Martín Bueno 1992 y 2017.

83 Muy similar a las catalogadas en Décor I, pl. 58, a y c, en un pavimento de Arcos de la Frontera y en otro de Germania.

84 De la Hoz - Jiménez 1986, 376, fig. 4. 
acanto, ${ }^{85}$ cuatro filetes de teselas, tres gruesos de cuatro hileras y uno de dos, alternando negro y blanco, por fin una gruesa trenza de tres cabos polícromos sobre fondo oscuro, ${ }^{86}$ un filete de dos hileras de teselas blancas y un cuadro enmarcado por un filete de teselas negras.

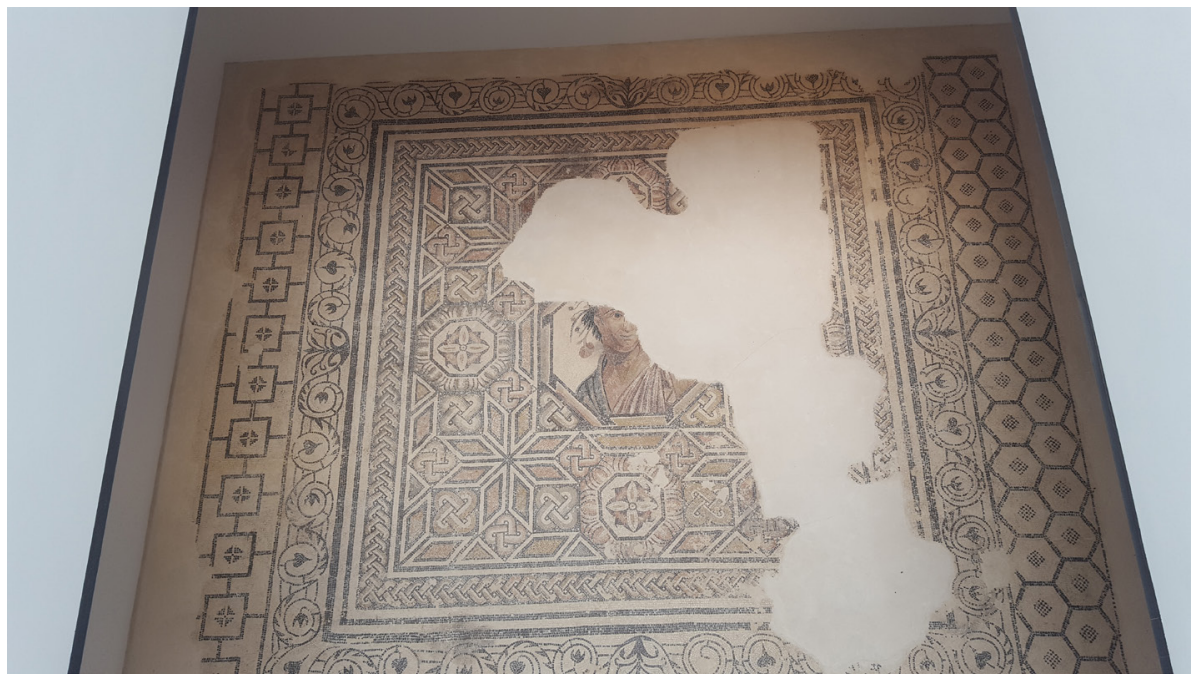

Fig. 6. Mosaico de la estancia no 5, "El Alcaparral” (Fotografía: Luz Neira)

El campo está basado en una composición centrada, en un cuadrado que contiene un octógono, y alrededor de un cuadrado, acotado de cheurones, de cuatro octógonos laterales, al cuadrado central, flanqueados por pares de rombos sobre las medianas, que simulan estrellas de ocho puntas, unidos entre sí (octógonos y estrellas) por cuadrados y cuadrados dispuestos sobre la punta, ambos decorados en su interior con un nudo de Salomón. Esta composición parece una adaptación del modelo representado en un mosaico de Italica $^{87}$ y en otro que se conserva en uno de los pavimentos de la villa de "La Estación" en Antequera, donde, sin cuadrado central, se documenta la composición ortogonal de estrellas de ocho puntas, unidas por pequeños cuadrados dispuestos sobre la punta y cuadrados. ${ }^{88}$ Los cuatro octógonos están decorados con un florón de cuatro hojas y en el cuadrado central se inscribe un gran octógono que deja como resultante, en las cuatro esquinas, triángulos isósceles rellenos con medio nudo de Salomón.

El octógono está silueteado por una línea de meandro fraccionado con oblicuas abiseladas $y$, aunque en estado muy fragmentario, contiene el busto de una figura varonil con una diadema de flores o pámpanos (Fig. 7), que fue muy bien interpretada ya en la época de su hallazgo como una imagen alegórica ${ }^{89}$ pues, recuérdese que, a pesar de los frutos y de la iconografía similar a la de las Estaciones que podría inducir al error de considerarla representación de una de ellas, acaso de la Primavera,

\footnotetext{
Décor I, 64, e.

Décor I, 72, d.

Décor II, pl. 388, c y d, este último de Italica.

Mañas - Vargas 2007, 319, fig. 3.

De la Hoz - Jiménez 1986, 372.
} 
su figuración como imagen única y protagonista en el octógono central del mosaico, de esquema predominantemente geométrico, descarta semejante hipótesis. A la hora de su identificación, es preciso que no se trataría de una alegoría de las más frecuentes en la musivaria romana, en su mayoría pertenecientes al género femenino, ya que es indudable su correspondencia a una figura masculina. A este respecto, el hecho de que se trate del busto de un joven e imberbe varón, con uno de sus hombros al descubierto y con el cabello ornado con flores y frutos como símbolos de renovación, fertilidad y abundancia, podría aludir a una representación de Annus, el Genio del Año, que está documentado en algunos mosaicos de la Península Itálica y España ${ }^{90}$ y, en particular, del norte de África, ${ }^{91}$ si bien la laguna que afecta a parte del busto nos impide saber si portaba el característico cuerno de la abundancia, además de carecer de la compañía de las Estaciones, que sí rodean según diferentes esquemas compositivos al Genio del Año en los mosaicos de las provincias romanas del norte de África, ${ }^{92}$ simbolizando la fertilidad en el transcurso de todo el año.

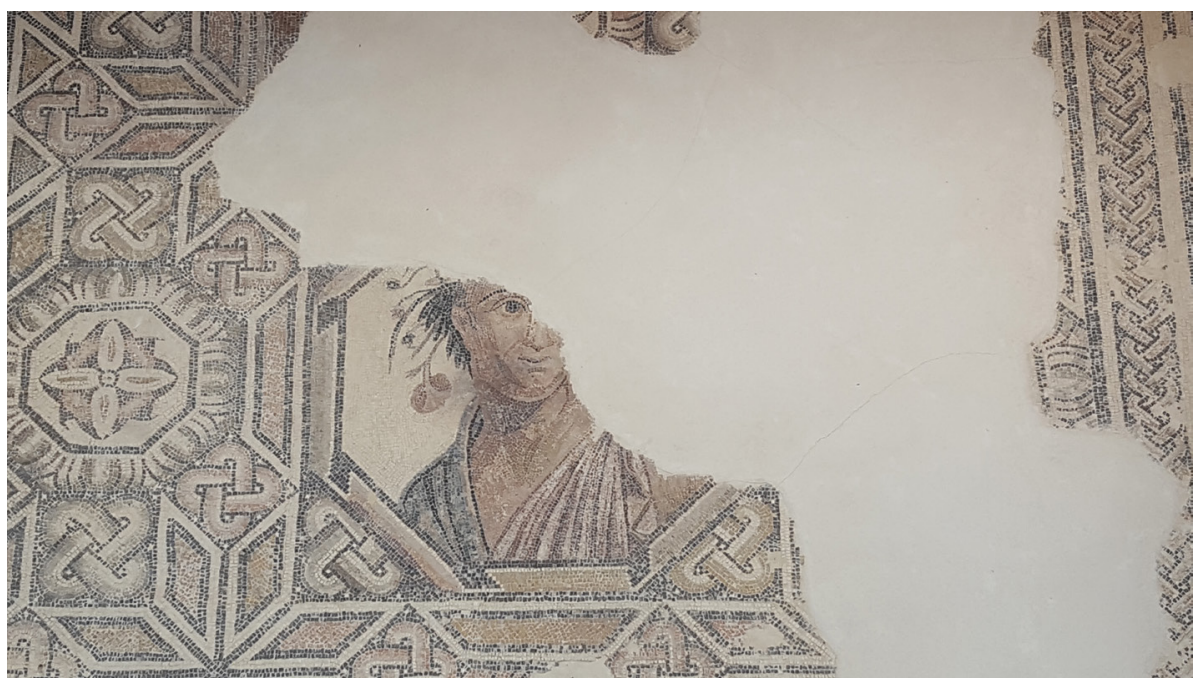

Fig. 7. Mosaico de la estancia $n^{\circ} 5$, "El Alcaparral”; detalle de la personificación alegórica (Fotografía: Luz Neira)

Es preciso señalar, no obstante, sin la compañía de las Cuatro Estaciones, el busto representado en el panel central, a modo de emblema, de un mosaico que pavimentaba la estancia de acceso a la habitación $\mathrm{n}^{\mathrm{o}} 1$ de la denominada domus de Narciso en Antioquía del Orontes, hallado durante las excavaciones de los años 30 en la zona residencial de Daphne. ${ }^{93}$ Conservado en el Metropolitan Museum, las informaciones de la página web del Museo lo describen como un busto femenino, con una corona de flores en la cabeza y una guirnalda floral sobre su hombro izquierdo, que tradicionalmente lo identificaría como la Primavera, si bien es probablemente una representación de una personificación más genérica de abundancia y buena vida, muy

\footnotetext{
Fernández Galiano et alii 1987, 175-183.

Foucher 1981, 3-10; Parrish 1981, 11-25.

Foucher 1981, 3-10; Parrish 1981, 11-25; 1984.

Levi 1947, 60-66, pl. X, a.
} 
adecuada a la atmósfera de lujo en la que vivían los domini de Daphne. ${ }^{94}$ A nuestro juicio, no obstante, se trataría de un busto de varón, según ya señaló Kondoleon, ${ }^{95}$ que ofrece un paralelo evidente sobre el simbolismo del busto representado en el mosaico $\mathrm{n}^{\circ} 5$ que pavimentaba el oecus, y cuya elección habría estado motivada por el deseo del dominus de "El Alcaparral" de mostrar nociones vinculadas a la estabilidad de la civilización alusiva a la ideología imperial que aporta fertilidad y, en suma, prosperidad, en cierto sentido en una línea similar a las Estaciones y a Annus.

Las excavaciones en esta estancia evidenciaron la caída de cemento en la esquina suroeste del mosaico $\mathrm{n}^{\circ} 5$, lo que hizo plantearse a los arqueólogos la existencia de dos pisos. Asimimo, los hallazgos hacia el sur y sureste, es decir, las estancias $\mathrm{n}^{\mathrm{o}} 7$ y 8 , y el resto minúsculo de la $\mathrm{n}^{\circ} 15$, de teselado cerámico, donde fueron hallados numerosos restos de dolia, condujeron a los arqueólogos a identificar esa zona como la pars rustica. ${ }^{96}$ Otro dato importante de aquella campaña es la composición del terreno donde se levantó el edificio de la villa en tres terrazas, hallándose la mayoría de los mosaicos en la terraza media, salvo $\operatorname{los} \mathrm{n}^{\circ} 15$ y 7 , que frente $a \mathrm{n}^{\circ} 5$ presentaba una diferencia de $1,10 \mathrm{~m}$ de altura.

Retornando a la pars urbana de la villa, el regreso desde las estancias el $\mathrm{n}^{0} 5 \mathrm{y}$ 3 a la $\mathrm{n}^{\mathrm{o}} 1$, pavimentada con el mosaico decorado con la escena del Juicio de Paris, nos conduce a seguir ahora el eje longitudinal, lo cual supone acceder al atrio con doce columnas de ladrillos semicirculares, pavimentado con un mosaico de motivos geométricos, $\mathrm{n}^{\mathrm{o}} 2$, que bordea por los cuatro lados el impluvium, decorado a su vez con un mosaico de tema marino, $\mathrm{n}^{\circ} 9$.

Según ya se ha indicado, el mosaico $\mathrm{n}^{\mathrm{o}} 2$ fue hallado en la primera campaña (Fig. 8), muy dañado y con muestras de haber sido restaurado en la Antigüedad como el mosaico $\mathrm{n}^{\circ} 4$. Estaba bordeado por un meandro de esvásticas con vuelta simple (en negro sobre blanco) ${ }^{97}$ a lo largo del campo geométrico sobre los cuatro corredores. La composición está basada en la disposición de un cuadrado y alrededor de un cuadrado dispuesto sobre la punta, y entre ellos rectángulos decorados con una trenza y rectángulos decorados con un rombo. Los cuadrados dispuestos sobre la punta iban silueteados por una trenza o por una línea de triángulos escalonados y rellenos estos de un trenzado de varios cabos. Sin paralelos claros, la más próxima es la documentada en Diekirch (Luxemburgo), ${ }^{98}$ aunque como motivo de una composición centrada.

Al acceder desde la estancia $n^{\circ} 1$ con el Juicio de París y atravesar el lado sur del corredor pavimentado con el mosaico $\mathrm{n}^{\mathrm{o}} 2$, se observaba, rodeado por las doce columnas citadas y a una mayor altura, el impluvium, pavimentado con el mosaico $\mathrm{n}^{\circ} 9$, cuya forma cuadrada quedaba quebrada en el lado superior, desde la entrada, con un espacio central sobresaliente. A juzgar por el informe de la campaña de 1986 y por la memoria sobre la extracción de los mosaicos en noviembre de $2000,{ }^{99}$ el pavimento se encontraba muy deteriorado por el hundimiento de la cisterna bajo el peso del terreno, de modo que tan solo sus restos figuran actualmente

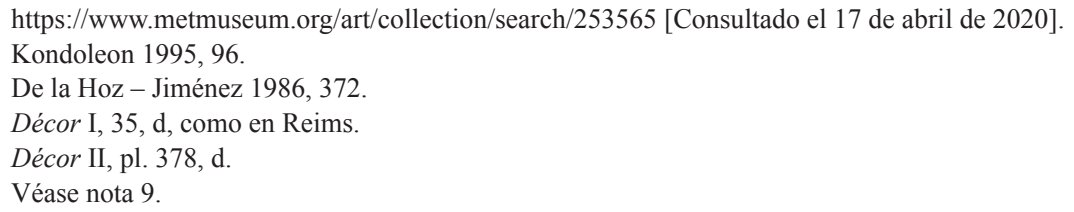


expuestos en la Colección Museográfica, cubriendo el suelo de una sala como en origen (Fig. 9).

Está bordeado por un filete de una hilera de teselas negras, una orla de pares de ondas en degradado horizontal, opuestas a cada lado de una especie de husos horizontales, ${ }^{100} \mathrm{y}$ un filete de tres hileras de teselas negras. En el campo figurado, sobre el fondo blanco, líneas de varias hileras de teselas en gris en sentido horizontal y salpicadas en vertical de tres en tres, de cuatro en cuatro y más, y líneas a modo de signos de cierre de un paréntesis simulan el movimiento de las aguas sobre la que figuran varios peces, causando un efecto espectacular, máxime cuando el estanque estuviera cubierto de agua.

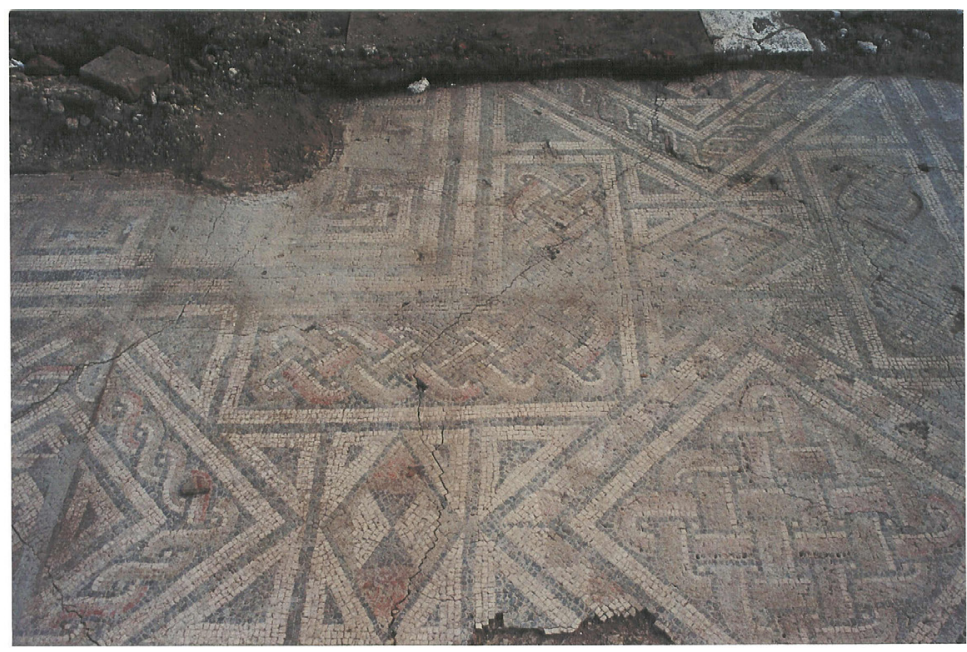

Fig. 8. Mosaico del atrio, estancia no 2 , de "El Alcaparral"; detalle (cortesía Colección Museográfica del Mosaico Romano, Casariche)

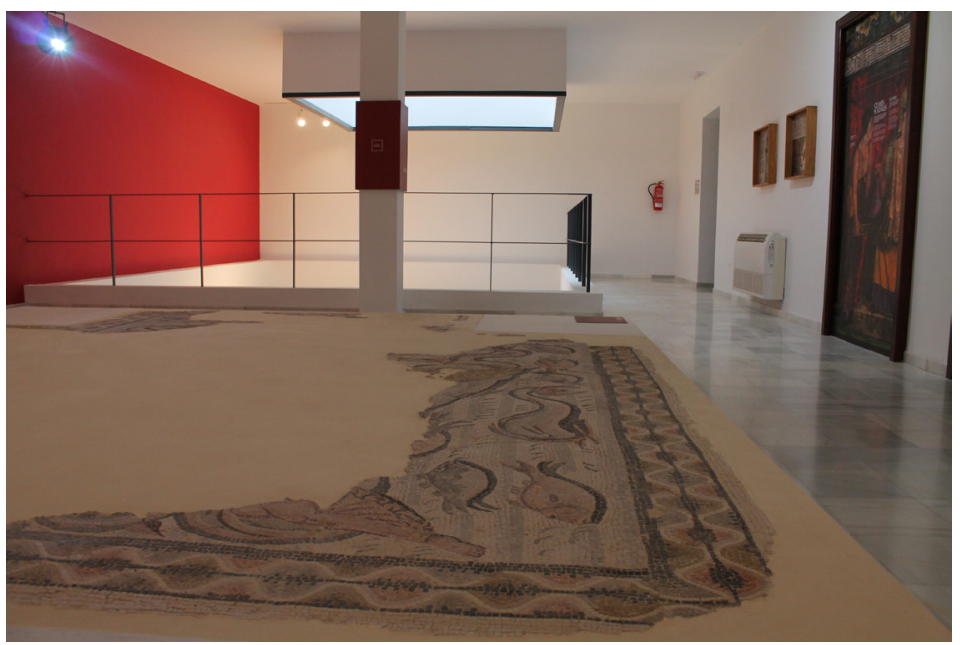

Fig. 9. Mosaico de thiasos marino, "El Alcaparral” (Fotografía: Luz Neira)

100 Algo similar similar a Décor I, pl. 61, como en Piazza Armerina (Carandini et alii 1982, 177, fig. 91, F XXIV). 
A pesar del estado muy fragmentario, en el ángulo inferior izquierdo, donde aparecen dos peces, se aprecia la pierna izquierda desnuda y en diagonal de una figura junto a la cola pisciforme de un tritón, animal o monstruo marino, que debía avanzar hacia la izquierda, como es habitual de cara al exterior, sobre el lado izquierdo del pavimento. Sin duda es la representación de una nereida. A mi juicio correspondería al tipo 1, según el cual las nereidas figuran de cara al espectador, vistas de tres cuartos, casi de perfil, junto a la cola pisciforme de su montura. ${ }^{101}$ Como alguna de estas, portaba como atributo el tallo de una hedera, según es característico de muchas nereidas (Fig. 10).

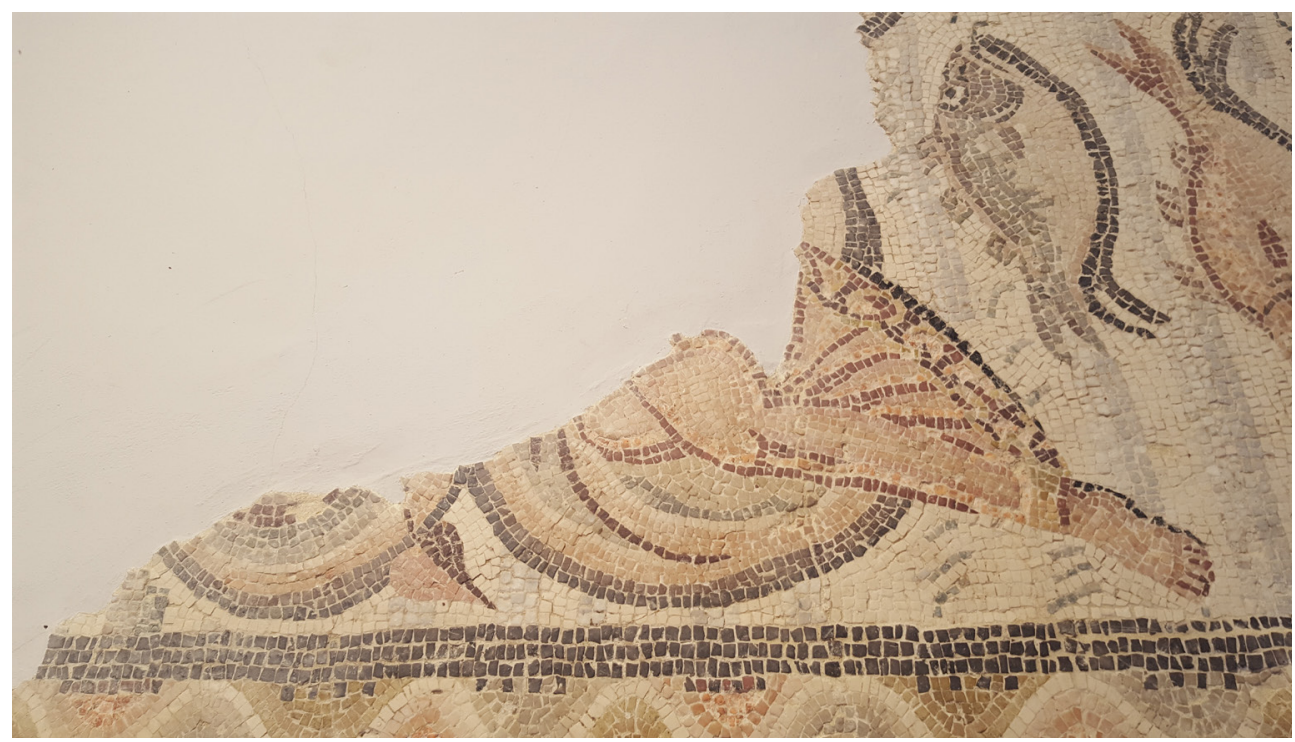

Fig. 10. Mosaico de thiasos marino, "El Alcaparral"; detalle de una nereida (Fotografía: Luz Neira)

Junto a los dos peces mencionados, que han sido representados uno sobre otro en direcciones opuestas, aparece un delfín, avanzando de perfil hacia la izquierda en el centro del lado inferior, seguido por tres peces, aunque el intermedio avanza en sentido inverso. Sobre ellos, se divisa parte de la sinuosa cola pisciforme, incluida parte de la aleta caudal trifoliata, de un tritón, animal o monstruo marino que, ocupando prácticamente el lado inferior, avanzaba hacia la izquierda, portando una nereida, de la que tan solo se aprecia su pierna derecha cubierta por un manto sobre el que debía asentarse. A juzgar por lo conservado es una representación de nereida perteneciente al tipo 3, de aquellas que figuran de tres cuartos al espectador asentadas sobre la cola psiciforme de su montura en sentido inverso a la marcha del animal (Fig. 11). Se desconoce, no obtante, si iría originariamente apoyada con su mano o antebrazo derecho en el principio de la cola pisciforme, ni los atributos que portaba.

101 Según la clasificación tipológica de las nereidas en los mosaicos romanos, Neira 1997, 386-402; 2002, 48-129. 


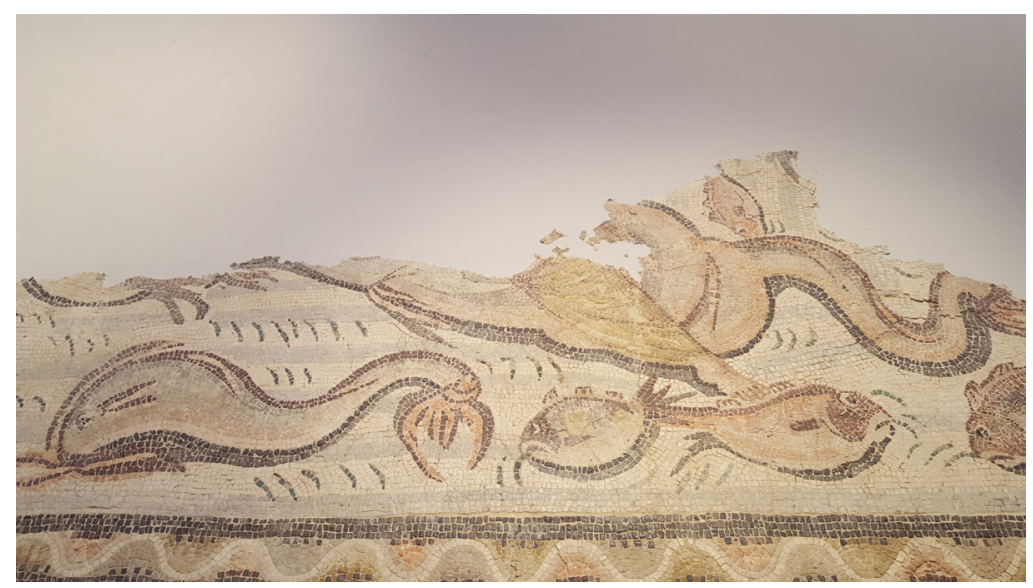

Fig. 11. Mosaico de thiasos marino, "El Alcaparral"; detalle de otra nereida

(Fotografía: Luz Neira)

Completamente destruido el lado derecho, en el espacio superior, que excede la forma cuadrada, por tanto, de menor longitud, se conserva también de cara al exterior la parte anterior de un monstruo marino, que avanza hacia la derecha. Por sus extremidades anteriores, similares a las de un felino, dotadas de aletas, y el largo cuello, sin que se conserve la cabeza, no obstante vuelta en dirección opuesta a la marcha, creemos que se trataría de un ketos ${ }^{102}$ en concreto de aquellos que muestran extremidades anteriores de un felino (Fig. 12), en lugar de grandes aletas natatorias.

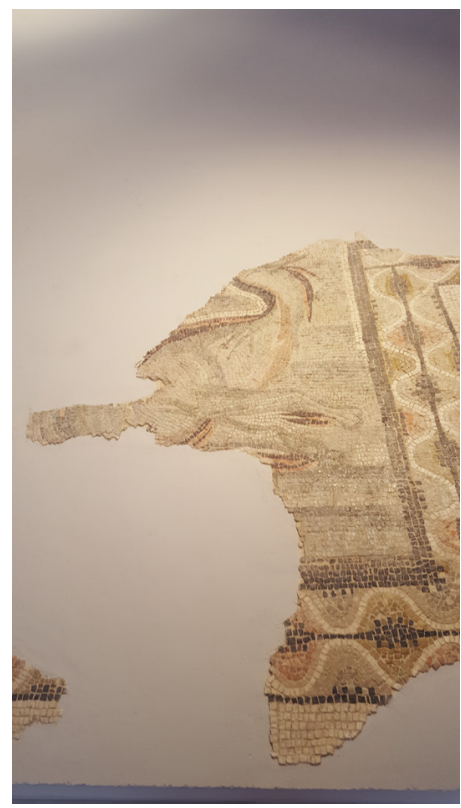

Fig. 12. Mosaico de thiasos marino, "El Alcaparral"; detalle del ketos (Fotografía: Luz Neira)

\footnotetext{
102 Sobre el origen del ketos, la referencia más antigua se encuentra en La Odisea (Hom. Od. 12.97).
} 
Entre las más de 450 nereidas documentadas en los mosaicos romanos, un número cercano a la treintena aparece sobre un ketos, una de las monturas más antiguas documentadas desde fin de época clásica y el helenismo, junto a hipocampos y delfines, que, a semejanza de ellos, más tarde darían lugar a un sinfín de distintos híbridos. A este respecto, nereidas de diferentes tipos sobre un ketos están documentadas en pavimentos ${ }^{103}$ predominantemente blanquinegros de la Península Itálica, en las termas de San Cesareo de Appia, Roma ( $\left.{ }^{\circ} 5\right)$, en el mosaico perdido de Porta Capena $\left(\mathrm{n}^{\circ} 15\right)$ y en las afueras, en el mosaico polícromo de Tor di Tre Teste ( $\left.{ }^{\circ} 43\right)$, en las termas de Via Terracina ( $\left.n^{\circ} 52\right)$, en el frigidarium de las termas de la Basilica Cristiana de Ostia ( $\mathrm{n}^{\circ}$ 69), en las Termas del Faro de Ostia ( $\left.{ }^{\circ} 84\right)$, en Castelporziano ( $\mathrm{n}^{\circ}$ 95) y en Ciciliano ( $\left.\mathrm{n}^{\circ} 103\right)$, así como en el gran pavimento polícromo de Arión en Piazza Armerina ( $\left.\mathrm{n}^{\circ} 131\right)$. También en mosaicos polícromos de las provincias del norte de África, como en la Casa del Procurador de Hippo Regius (156), en Maxula ( $\left.\mathrm{n}^{\mathrm{o}} 162\right)$, en las Termas de Theveste $\left(\mathrm{n}^{\circ} 183\right)$, en Thugga $\left(\mathrm{n}^{\circ} 194\right)$, en las Termas de la Casa de Catón en Utica $\left(\mathrm{n}^{\circ} 214\right)$, en Cillium $\left(\mathrm{n}^{\mathrm{o}} 226\right)$, en el oecus de la Casa de Sorothus en Hadrumetum $\left(\mathrm{n}^{\circ} \mathrm{s} .235,245,250,259\right.$, en las termas de Tagiura $\left(\mathrm{n}^{\circ} 294\right)$, en Lambaesis ( $\left.\mathrm{n}^{\circ} 307\right)$, en las Termas de Sila $\left(\mathrm{n}^{\circ} 315\right)$ y en Auzia ( $\left.\mathrm{n}^{\circ} 320\right)$. Asimismo, nereidas sobre ketoi están documentadas en otros tres mosaicos hispanos, en la villa del Hinojal ( $\mathrm{n}^{\mathrm{o}} 357$ ), en la antigua Caesaragusta ${ }^{104} \mathrm{y}$ en el pavimento de la villa de Salar, ${ }^{105}$ por orden cronológico de hallazgo.

En los mosaicos citados se encuentran dos variedades de ketoi, los que muestran extremidades anteriores propias de un felino y los que, en cambio, como en Salar, presentan aletas natatorias. A este respecto es de resaltar que en el mosaico que pavimentaba el gran oecus de la domus de Sorothus en Hadrumetum, ${ }^{106}$ donde entre las numerosas nereidas, que forman parte de un gran thiasos marino en virtud de la escena principal con el Triunfo de Neptuno, se concentra el mayor número de nereidas de diferente tipo asociadas a un ketos, se documentan tres de ellas sobre ketoi de extremidades anteriores felinas y dos sobre otros tantos con aletas natatorias.

Nereidas asociadas a ketoi son, por tanto, frecuentes en la musivaria itálica y norteafricana, mientras que hasta hace unos años tan solo aparecía atestiguada la muy afectada por una laguna en el citado pavimento lusitano del "Hinojal" y, posteriormente, una de las dos nereidas representadas en varios fragmentos de un pavimento en Caesaragusta, por lo que la nereida de Salar ${ }^{107}$ y la de Casariche han venido a documentar este tipo de asociación en los mosaicos de la Baetica. Es de resaltar además que ketoi de los dos tipos están documentados en la musivaria hispana, con aletas natatorias en Salar, con patas de felino en Caesaraugusta y El Alcaparral.

Estaríamos por tanto ante una composición de nereidas sobre monstruos marinos, dispuestos sobre los lados de cara al exterior, ${ }^{108}$ como miembros de un cortejo protagonista en sí mismo del campo figurado, según se documenta en numerosos

103 Neira 1992a, a cuyos números de catálogo se remite en el texto al citar las diferentes nereidas sobre un ketos.

104 Neira et alii 2016, 683-693, láms. I-III.

105 González - El Amrani 2013.

106 Foucher 1960, 57, nº Inv. 57.119.

107 Sobre la nereida de Salar, Neira et alii 2016.

108 Neira 1992, 341-348, según se aprecia ya en pavimentos blanquinegros de la primera mitad del siglo II, todavía en torno a una figura o escena principal. 
mosaicos, donde no siempre aparecen en función de una figura o escena principal. ${ }^{109}$ Entre los paralelos que confieren al cortejo en sí mismo todo el protagonismo de la composición se encuentran el pavimento bícromo de las termas situadas junto a la vía que unía Puteoli y Neapolis,${ }^{110}$ fechado a principios del siglo II, con cuatro nereidas sobre monstruos marinos, uno de los mosaicos de la villa de Munatia Procula,${ }^{111}$ del 123, con Ulises, Scylla y una nereida sobre grifo marino sobre tres de sus lados, un mosaico de Via Cornelia, ${ }^{112}$ de finales del II ó principios del III, con cuatro nereidas sobre monstruos marinos, un mosaico de los horti Asianiani, ${ }^{113}$ otro de Porta Capena, ${ }^{114}$ un pavimento de las termas de la Basilica Cristiana ${ }^{115}$ y otro de las termas del Faro, ya de mediados del III, un pavimento de las termas de los Siete Sabios, ${ }^{116}$ entre los ostienses, un pavimento del norte de África, el de Tagiura ${ }^{117}$ y en el oriental de Nisibis, ${ }^{118}$ donde tres nereidas sobre tritones figuran en torno a un pequeño estanque de forma cuadrada. ${ }^{119}$ A este respecto, es de señalar que en algunos de estos casos -como también en el mosaico hispano hallado en Santiponce que se conserva en el Museo Arqueológico de Sevilla, ${ }^{120}$ de principios del siglo III, con los cuatro tritones de cara al exterior como únicos miembros de un cortejo, protagonista de la composición- los mosaicos pavimentan el suelo de una fuente o estanque, que, una vez cubiertos de agua, reflejaban una imagen ciertamente espectacular de nereidas, tritones, monstruos marinos y otras especies en el escenario marino, tal y como debió suceder, sin duda, en el impluvium de la residencia de "El Alcaparral".

Desde la zona este del atrio con impluvium, el plano de la domus realizado tras las excavaciones de 1986 sitúa la estancia $n^{\circ}$ 6, que fue identificada con un cubiculum, como la habitación $n^{\circ} 4$. Por desgracia, apenas restaba nada de su pavimento.

Por el lado norte del atrio se accedía a la habitación $n^{\circ} 11$, identificada también con un cubiculum, como las $n^{\circ} 4$ y 6 . El pavimento (Fig. 13), que se expone en la Colección Museográfica de Casariche, se encontraba bastante deteriorado, pero sí se aprecia una línea ondulante en negro sobre blanco, con motivos en los intervalos, poco común, y tres filetes de tres hileras de teselas negras entre dos bandas de teselas blancas que rodean la composición ortogonal de pares tangentes de peltas adosadas, alternativamente horizontales y verticales, ${ }^{121}$ terminadas en crucecitas. ${ }^{122}$

Por el centro del lado norte del atrio se accede también a la estancia 10, identificada en el Informe de 1986 como tablinum, a través de la cual se daba paso a la habitación $\mathrm{n}^{\mathrm{o}} 13$ y por un pasillo a la $\mathrm{n}^{\mathrm{o}} 12$, interpretado como un oecus.

\footnotetext{
09 Neira 1992, 348-350.

110 Neira 1992, 69-72, $n^{\circ}$ cat. 39.

111 Neira 1992, 48-49, $\mathrm{n}^{\circ}$ cat. 26.

112 Neira 1992, 52-53, $\mathrm{n}^{\mathrm{o}}$ cat. 29.

113 Neira 1992, 40-42, $n^{\circ}$ cat. 19

114 Neira 1992, 13-14, $\mathrm{n}^{\mathrm{o}}$ cat. 3.

115 Neira 1992, 87-88, $n^{\circ}$ cat. 51.

116 Neira 1992, 96-97, $\mathrm{n}^{\mathrm{o}}$ cat. 55.

117 Neira 1992, 304-305, no . cat. 147.

118 Neira 1992, 505-507, $\mathrm{n}^{\circ}$ cat. 230.

119 Neira 1992, 505-507, $\mathrm{n}^{\circ}$ cat. 230.

120 Neira 1994, 359-367.

121 Décor I, 222, d, como en Acholla.

122 Décor I, 222, f, como en Antioquía.
} 


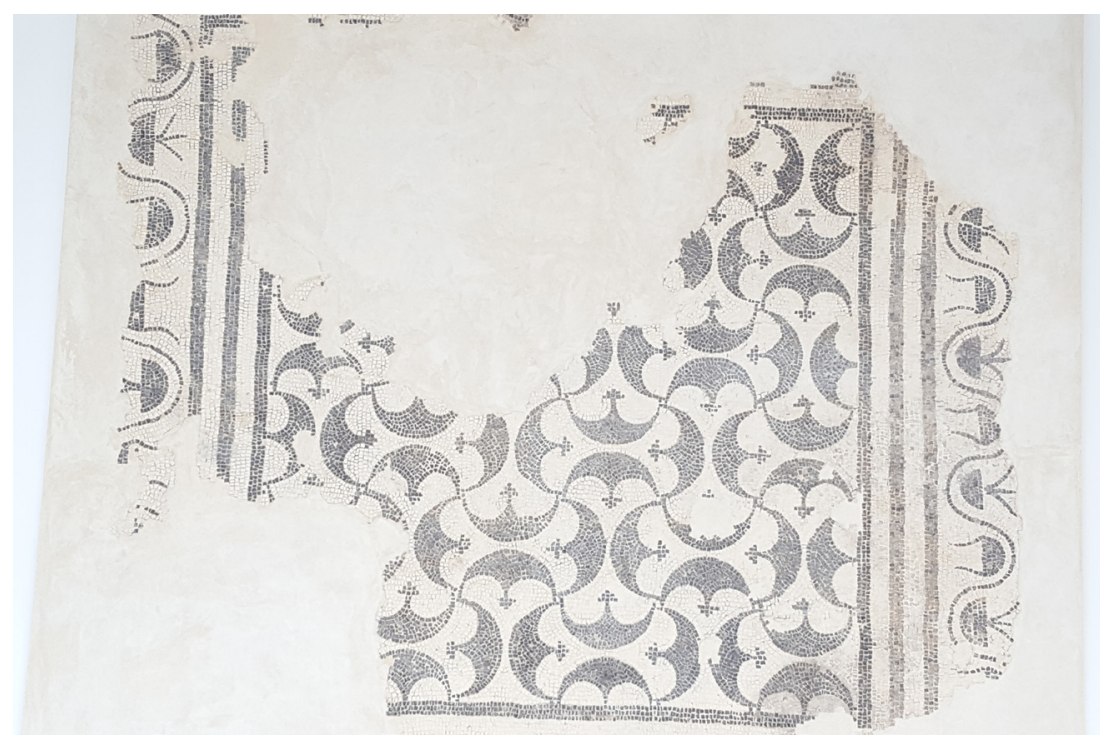

Fig. 13. Mosaico de la estancia n 11, "El Alcaparral” (Fotografía: Luz Neira)

El mosaico de la estancia $\mathrm{n}^{\circ} 10$ estaba bastante bien conservado (Fig. 14). Expuesto en la Colección Museográfica, muestra un umbral de acceso, de forma rectangular con un damero de rombos en blanco y negro, ${ }^{123}$ y una orla de enmarque compuesta por una línea de peltas verticales, afrontadas a cada lado de un rombo horizontal, ${ }^{124}$ decorado en su interior con una roseta longuiforme. Esta línea se documenta también en dos mosaicos de Astigi, si bien en uno de ellos ${ }^{125}$ las peltas son negras, no tienen el enrollado habitual y los rombos contienen otros rombos en su interior del mismo color, mientras que en el otro, con representación de circo, ${ }^{126}$ los rombos contienen un nudo de Salomón. Se trata de una decoración de influencia africana muy frecuente en el sur de la Península Ibérica como decoración de orlas, ya que también se documenta en la villa de La Estación, ${ }^{127}$ en la de Los Torrejones, ${ }^{128}$ y en la villa de Panes Perdidos. ${ }^{129}$ El campo está decorado con una composición ortogonal de octógonos irregulares secantes y adyacentes por los lados cortos, tratados en meandros de esvásticas, ${ }^{130}$ pero con rosetas longuiformes. ${ }^{131}$

A través de un corredor en paralelo a la estancia $\mathrm{n}^{\circ} 11$, desde la $\mathrm{n}^{\circ} 10$ se accede a la habitación $n^{\circ} 12$. El mosaico $n^{\circ} 12$ (Fig. 15), que también figura expuesto en la Colección Museográfica, presenta una orla en blanco y negro con cuadrados trazados intercalados a un lado y otro con roseta de cuatro pétalos en el centro. A continuación una trenza de varios cabos polícroma bordea la composición ortogonal

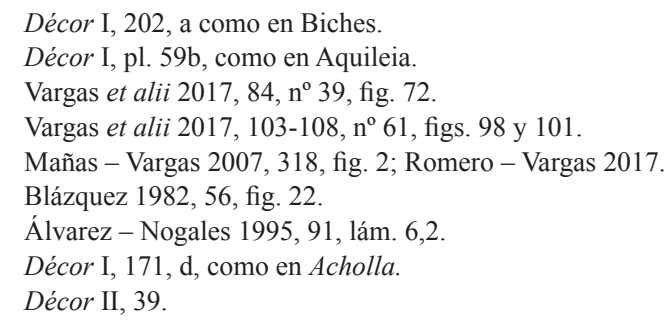


de octógonos adyacentes, 4 líneas por 8 líneas, formando cuadrados dispuestos sobre la punta, trazados en negro, ${ }^{132}$ con otro más pequeño inscrito en su interior en teselas rojas, dando lugar a trapecios en los cuatro lados, mientras los octógonos inscriben otro octógono con un florón compuesto de ocho elementos no contiguos, cuatro de pétalo fusiforme y cuatro de loto trífido, aquí alrededor de un círculo, de color blanco.

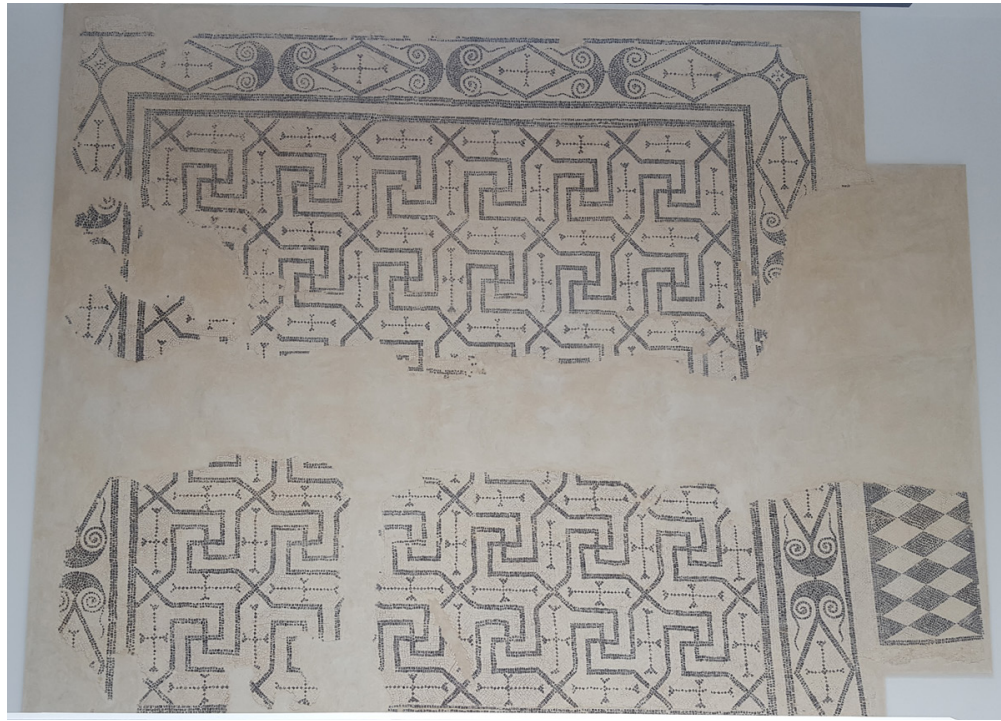

Fig. 14. Mosaico de la estancia n 10, "El Alcaparral” (Fotografía: Luz Neira)

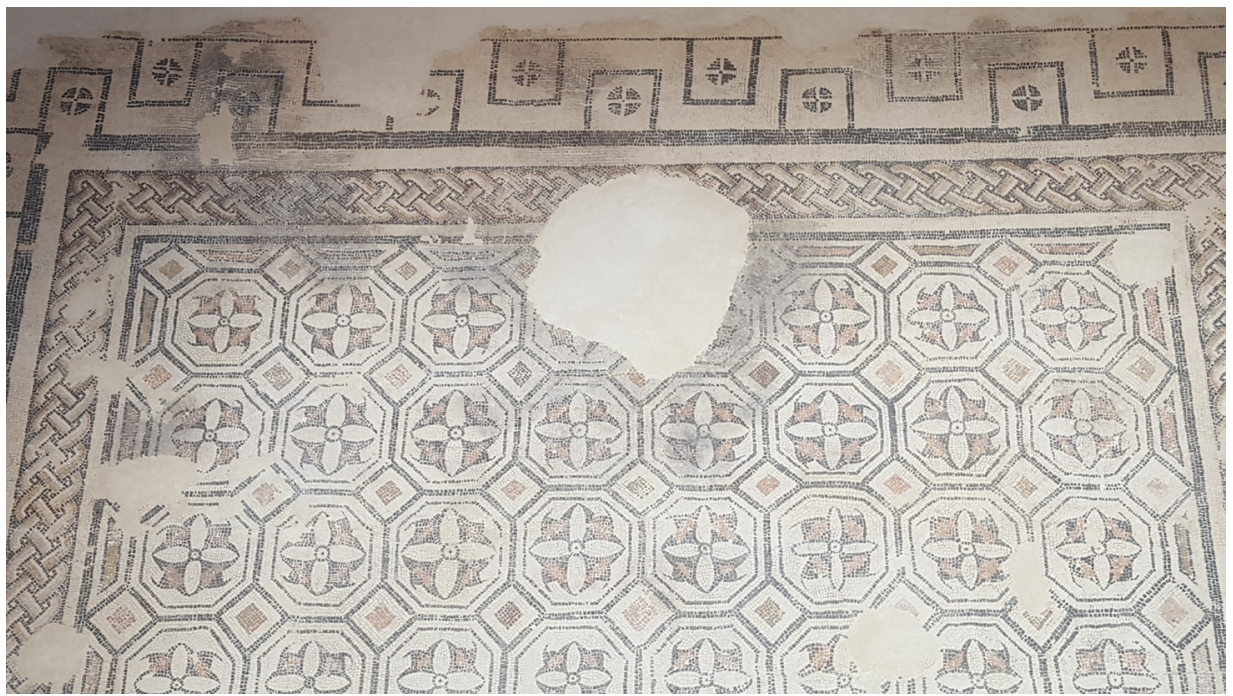

Fig. 15. Mosaico de la estancia no 12, "El Alcaparral” (Fotografía: Luz Neira)

132 Décor I, 167, a. 
Desde la sala $\mathrm{n}^{\mathrm{o}} 10$ también se accede a la estancia rectangular $\mathrm{n}^{\mathrm{o}} 13$, con un pavimento (Fig. 16) que presenta una línea de arcadas trazadas en teselas negras sobre blanco, en blanco y negro, en torno a una composición geométrica basada en una composición ortogonal de meandros de esvásticas en paletones de llave dobles, ${ }^{133}$ pero con cuadros trazados con un filete con dentículos $\operatorname{largos}^{134} \mathrm{y}$ decorados con trenzado, pequeños y grandes. La orla es muy similar a la documentada en un pavimento de la villa de "La Estación" 135 y similar a la de un mosaico de Martos. ${ }^{136}$

Junto a esta estancia fue localizada en la campaña de 1986 otra habitación, la no 14, sobre cuyo pavimento, muy deteriorado, fue hallada la citada moneda de Filipo el Árabe (244-249).

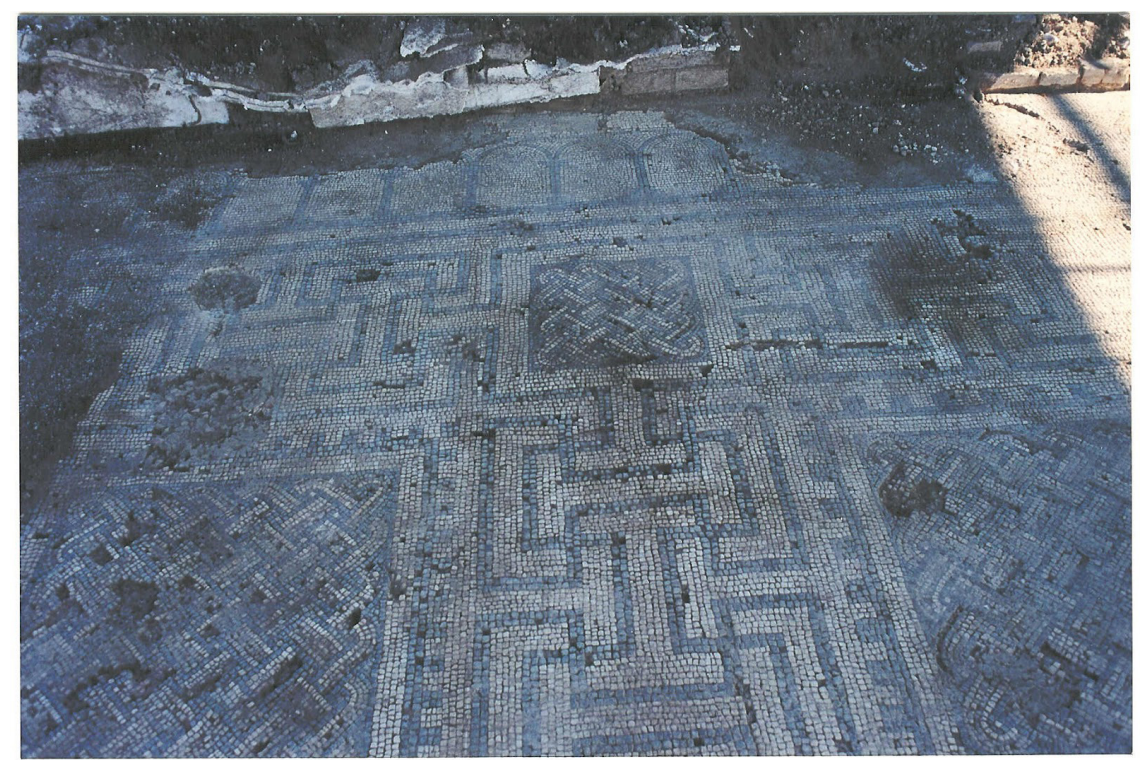

Fig. 16. Mosaico de la estancia n ${ }^{\circ} 13$, "El Alcaparral" (cortesía de la Colección Museográfica del Mosaico Romano, Casariche)

\section{Consideraciones sobre el programa iconográfico de la decoración musiva de la villa de "El Alcaparral"}

A juzgar por todo lo expuesto, uno de los aspectos más sobresalientes de la primera campaña de excavaciones arqueológicas de urgencia acometida en la finca de "El Alcaparral" en julio de $1985^{137}$ fue la realización de una cata en el mosaico del Juicio de Paris, con el objetivo de comprobar la composición de su lecho, lo que puso de manifiesto la constatación de que el célebre mosaico se encontraba sobre un pavimento anterior, a $10 \mathrm{~cm}$. ¿Podría, a este respecto, deducirse que el mosaico

133 Décor I, 188, d, como en Bavay.

134 Décor I, 2, 1.

135 Mañas - Vargas 2007, 334, fig. 14; Romero - Vargas 2017.

136 Recio 1973, 640, fig. 20; Blázquez 1981, 62-63.

137 Jiménez et alii 1985, 274. 
del Juicio habría formado parte de un proceso de monumentalización del edificio residencial de la villa, que, por tanto, habría tenido una fase anterior?

Como se acaba de señalar, los arqueólogos que llevaron a cabo la segunda campaña de excavaciones en 1986 consignan en su informe el hallazgo de una moneda de Filipo el Árabe (244-249) sobre el mosaico $n^{\circ} 14$, lo que les indujo a plantear una cronología para el inicio de la villa "en el siglo III, después de la crisis de estos agitados tiempos", añadiendo que "hasta el momento no ha aparecido nada que se pueda considerar anterior", ${ }^{138} \mathrm{y}$, en alusión a las monedas descubiertas en la primera campaña, fuera del "recinto" como resultado de una ocultación, "que pertenecen a una época que va desde mediados del siglo IV hasta principios del V" citan una de Honorio, cuya amonedación data del 393-395 o 395-408, lo que les condujo a plantear para la destrucción y abandono un periodo entre mediados del siglo IV y principios del V, época a la que atribuyen la sigillata $\mathrm{C}$ y $\mathrm{D}$ hallada en la primera campaña. ${ }^{139}$

Otra cuestión fundamental fue la constatación durante la segunda campaña de que las estructuras de la pars urbana de la villa respondían a una planimetría en tres terrazas, $\mathrm{y}$, como dato más significativo, que la mayoría de los 15 pavimentos descubiertos, a excepción del $\mathrm{n}^{\mathrm{o}} 7$ y el $\mathrm{n}^{\mathrm{o}} 15$, se encontraba en la terraza media, dando lugar a la hipótesis de que los mosaicos hallados correspondían a la misma fase de habitación de la villa.

Partiendo de esta base, a tenor del hallazgo sobre el deteriorado pavimento $\mathrm{n}^{\circ} 14$ de la moneda de Filipo el Árabe (244-249), podría plantearse la hipótesis de que los mosaicos descubiertos fueran de una época inmediatamente anterior no tanto a la fecha de acuñación sino a la etapa de circulación de la moneda, lo que supondría una cronología que podría abarcar desde mediados a la segunda mitad del siglo III, sin que parezca posible afirmar en la actualidad si la ocultación en el extrarradio -donde, como ya se advirtió supra $(\S 1)$, fueron hallados muros que delimitaban una estancia $\mathrm{y}$ en su interior una pequeña pileta excavada en el suelo, con las paredes revestidas por cuatro tégulas, y en torno a esta pileta una ocultación de 74 monedas, de época tardía, muchas de ellas de cecas orientales- habría coincidido con el abandono y la destrucción del edificio, tal y como documentan las huellas de incendio en los mosaicos en el primer cuarto del siglo V. ${ }^{140}$

Quedaría, no obstante, por explicar la superposición de los dos mosaicos en la sala denominada $\mathrm{n}^{\circ} 1$, donde apareció el mosaico del Juicio de Paris. Cabe plantearse, a este respecto, si el mosaico anterior -que, según la cata realizada en 1985, se encontraba a $10 \mathrm{~cm}$ - podría haber pertenecido a una fase de habitación más antigua, aunque no hay documentación sobre la existencia de mosaicos como el mencionado bajo los otros pavimentos que fueron descubiertos en 1985 y 1986 y extraidos en el año 2000.

No sería de extrañar la correspondencia del mosaico hallado $10 \mathrm{~cm}$ por debajo del mosaico de Paris a una fase anterior como ha sucedido en algunas villae hispanorromanas, ya que el conocimiento parcial de las mismas puede variar sustancialmente el contexto analizado con la reanudación de futuras excavaciones. ${ }^{141}$

\footnotetext{
38 De la Hoz - Jiménez 1986, 377.

139 De la Hoz - Jiménez 1986, 377.

140 Según manifestaban De la Hoz - Jiménez 1986, 377.

141 Neira 2020a, 43-67.
} 
Existen casos bien conocidos como el de Carranque (Toledo) en la Carthaginiensis en los que la musealización quizás prematura condicionó durante algunos años la visión de la residencia de la villa como construcción ex novo en época de Teodosio, cuando campañas posteriores sacaron a la luz evidencias de una villa anterior sobre la que posteriormente se habría erigido la mansión de Materno. ${ }^{142}$ Algo similar sucedió en Fuente Álamo (Puente Genil, Córdoba) en la Baetica, donde en 1982 se produjo el hallazgo fortuito en la margen izquierda del antiguo arroyo del célebre mosaico nilótico y que, según las directrices de la época, fue trasladado al Museo Arqueológico Provincial de Córdoba, donde todavía se encuentra. ${ }^{143}$ El descubrimiento de este mosaico, y su publicación algunos años después, ${ }^{144}$ puso de manifiesto el carácter único y excepcional de esta representación figurada, dando lugar además a diversas lecturas e hipótesis sobre la traducción de las inscripciones y su atribución a una obra o género determinado. ${ }^{145}$ Tres años más tarde, esta vez durante una excavación de urgencia en la margen derecha del arroyo, otra serie de mosaicos geométricos -y uno figurado, el de la lucha contra los indios y el triunfo de Dioniso, ${ }^{146}$ como pavimento de una gran estancia de cabecera absidada, probablemente el stibadium, precedido en el acceso al mismo de otro mosaico con tres escenas, entre las que destaca la representación de las Tres Gracias- ${ }^{147}$ fueron identificados como correspondientes a estancias de la pars urbana de una villa del siglo IV, a la que según su excavador habría pertenecido también el citado mosaico nilótico. ${ }^{148}$ Durante casi veinte años, tras el cese de las excavaciones, la visión de la villa de Fuente Álamo en la bibliografía científica se redujo a la planta de aquellas pocas estancias pavimentadas con estos mosaicos y al recuerdo del nilótico, como pertenecientes a una única fase de ocupación, hasta que las labores emprendidas en 2005 para el levantamiento del mosaico de Dioniso, con el fin de proceder a su restauración antes de volver a ser colocado in situ ${ }^{149}$ dieron como resultado el hallazgo bajo su lecho de un pavimento polícromo de motivos geométricos y de otro de similares características en el espacio contiguo, documentando un asentamiento más antiguo, quizás un balneum, que ponía en tela de juicio la hipótesis de una única fase de construcción del dominio. ${ }^{150}$ Las sucesivas campañas de excavación llevadas a cabo entre 2005 y 2009 sacaron a la luz nuevos restos y un número considerable de pavimentos, ${ }^{151}$ que revelaron una mayor extensión de la residencia del siglo IV, procediéndose en aquellos años a la realización de obras de musealización del yacimiento que, gracias al apoyo de la corporación municipal de Puente Genil, favorecerían el acceso de los visitantes a Fuente Álamo y la organización de numerosas actividades de difusión para contribuir al conocimiento del patrimonio arqueológico pontano. La prosecución de

142 Fernández Galiano 1989, 255-269; Fernández Ochoa et alii 2007, 743-753.

143 A pesar de haberse acordado en enero de 2017 el retorno del pavimento a su emplazamiento originario, en virtud de un compromiso entre la consejera de Cultura de la Junta de Andalucía, Rosa Aguilar, y el alcalde del Ayuntamiento de Puente Genil (Córdoba), Esteban Morales.

144 Daviault et alii 1987.

145 Gómez Pallarès 1989, 105-116; 1997; Teatini 2019; Ibba 2019, estos dos últimos con la bibliografía más reciente.

146 López Monteagudo et alii 1988, 785-816; Blázquez et alii 1993, 221-260; Lancha 2001, 161-176.

147 López Monteagudo et alii 1988, 785-816; Neira 2008, 287-300.

148 López Palomo 1985, 105-111.

149 Siguiendo las nuevas directrices.

150 Delgado - Jaén 2014, 74, n. 16.

151 López Palomo 2013-2014, 295-348. 
las excavaciones y un análisis riguroso de los mosaicos ha desvelado al menos dos fases de habitación y clarificado la pertenencia de los pavimentos a una u otra época en el asentamiento. ${ }^{152}$

Sin embargo, cabría pensar también que, en lugar de una fase anterior a la bien documentada en el edificio residencial de "El Alcaparral", pudiera tratarse de un primer pavimento que, en el transcurso de la ocupación de la villa en el periodo cronológico mencionado, hubiera sido objeto de una remodelación con la consiguiente realización del mosaico del Juicio de Paris. No obstante, mientras las excavaciones no se reanuden, resulta complicado aseverar una u otra hipótesis.

A juzgar por los datos disponibles en la actualidad, cierto es, en el proceso de pavimentación de la villa el programa iconográfico muestra la escena del Juicio orientada hacia el exterior, de modo que su contemplación habría sido una de las primeras imágenes figuradas, si no la primera, vista al entrar en la pars urbana de la domus, una auténtica declaración del propietario, cuya selección podría implicar la pretensión del comanditario que encargó la monumentalización de la residencia a la hora de mostrar su grado de cultura e incluso la interpretación alegórica del mito y de los poemas homéricos que constituían una práctica generalizada en el ámbito de las escuelas filosóficas y la producción artística. ${ }^{153}$ Junto a este mosaico, de leyenda bien conocida pero, aun a pesar de los últimos hallazgos hispanos, no demasiado representada en la musivaria, es de resaltar también el simbolismo del busto representado en el mosaico $\mathrm{n}^{\circ} 5$ que pavimentaba el oecus, y cuya elección habría estado motivada por el deseo del dominus de "El Alcaparral" de mostrarse afín a la ideología imperial que aporta fertilidad y, en suma, prosperidad, y todavía entre los figurados la representación del thiasos marino de nereidas sobre diferentes híbridos como pavimento del impluvium, con la finalidad de conseguir el efecto de reproducir un auténtico escenario marino.

Significativos son igualmente los otros 12 mosaicos restantes en diferente estado de conservación, que estaban decorados con motivos geométricos, con predominio de teselas blancas y negras y apenas algunas de color, pues refleja la tónica advertida ya en numerosas residencias de villae romanas de la Península, donde, como ya hemos señalado ${ }^{154}$ se puede apreciar el predominio de los pavimentos con esquemas geométricos, entre los que se hallaron asimismo hacia el sur y sureste, los mosaicos de las estancias $\mathrm{n}^{\mathrm{o}} 7$ y 8 , y el resto minúsculo de la $\mathrm{n}^{\mathrm{o}} 15$, de teselado cerámico, y numerosos restos de dolia, que condujeron a los arqueólogos a identificar esta zona como la pars rustica.$^{155}$ Todo ello sin menoscabo del programa iconográfico, ya que, precisamente, la excepcional representación de escenas figuradas en un pequeño número de mosaicos realza aún más si cabe la elección de las leyendas y personajes, poniendo el foco sobre el Juicio de Paris, la personificación alegórica y el thiasos marino en "El Alcaparral", que, sin duda, habrían sido destinadas a las estancias más significativas del edificio señorial.

152 Neira 2019, 279-322.

153 Según señala De Matteis 2004, 189.

154 Neira 2020b. Tal y como se ha indicado también al estudiar los mosaicos de Fuente Álamo, Neira 2019, 279322; 2020, 43-67.

155 De la Hoz - Jiménez 1986, 372. 


\section{Referencias bibliográficas}

Albertini, E.

(1920): "Mosaïque à figures trouvée à Cherchel", BCTH, CLXXIII-CLXXV.

(1921): "Mosaïques et inscriptions romaines trouvées à Cherchel”, BCTH, LXXVIIILXXIX.

Balil, A. (1989): “Algunos mosaicos de tema mitológico", BSAA 55, 113-148.

Balty, J. (1977): Mosaïques antiques de Syrie, Bruxelles.

Baratte, F. (1978): Catalogue des mosaïques romaines et paléochrétiennes du musée du Louvre, Paris.

Bazant, J. (1994): "Pothos”, LIMC VII/1-2, 501-503.

Blázquez, J. M ${ }^{\mathrm{a}}$

(1981): Mosaicos romanos de Córdoba, Jaén y Málaga, Madrid.

(1985): "Mosaicos romanos del Campo de Villavidel (León) y de Casariche (Sevilla)", Archivo Español de Arqueología 58, 107-124.

(2014): "Mitos del mosaico de Cástulo", 7 esquinas. Boletín del Centro de Estudios Linarenses 6, 109-116.

Blázquez, J. Ma et alii (1993): "Recientes hallazgos de mosaicos en Hispania (1977-1987)", ETF. Serie II, Ha Antigua 6, 221-296, 279-291 (https://doi.org/10.5944/etfii.6.1993.4216).

Buero, S. (1986): "Excavaciones de urgencia en la provincia de Sevilla", Revista de Arqueología 58, 59-60.

Carandini, A. et alii (1982): Filosofiana. La villa de Piazza Armerina, Palermo.

Carrillo, J. R. (1993): "Los estudios sobre las villas romanas de Andalucía: Una revisión historiográfica", Anales de Arqueología Cordobesa 4, 233-257.

Daviault, A. et alii (1987): Un mosaico con inscripciones / Une mosaïque à inscriptions, Puente Genil (Córdoba), (=Collection de la Casa de Velázquez 17), Madrid.

Décor I: Balmelle, C. et alii (1985): Le Décor géométrique de la mosaïque romaine I, Paris. Décor II: Balmelle, C. et alii (2002): Le Décor géometrique de la mosaïque romaine II, Paris.

De la Hoz, A. - Jiménez, J. C. (1986): "Informe de la segunda campaña de excavaciones en la villa romana de "El Alcaparral" (Casariche, Sevilla)", Anuario Arqueológico de Andalucía IV, 371-379.

Delgado, M. - Jaén, D. (2014): “Territorio y ciudad. El yacimiento arqueológico de Fuente Álamo, Puente Genil (Córdoba). A modo de reflexión”, [en] D. Vaquerizo et alii (eds.), Ciudad y Territorio: transformaciones materiales e ideológicas entre la época clásica y el Alto Medioevo (=Monografías de Arqueología Cordobesa 20), Córdoba, 69-84.

De Matteis, L. M.

(1999): "I mosaici romani dell'area delle Terme occidentali", [en] M. Ennaïfer - A. Rebourg (eds.), La mosaïque gréco-romaine VII: VII colloque international pour l'étude la mosaïque antique (Tunis 3-7 octobre 1994), Tunis, 59-67.

(2004): Mosaici di Cos. Dagli scavi delle missioni italiane e tedesche (1900-1945), Salerno.

Dunbabin, K. M. D. (2016): Theater and Spectacle in the Art of the Roman Empire, Ithaca.

Duval, Y. (ed.), (1981): Mosaïque Romaine Tardive. L'iconographie du temps. Les programmes iconographiques de maisons africaines, Paris.

Ferdi, S. (2005): Corpus des mosaïques de Cherchel, Paris.

Fernández Galiano, D. (1989): "La villa de Materno", [en] Mosaicos romanos. Actas de la I Mesa Redonda Hispano-Francesa sobre mosaicos romanos habida en Madrid en 1985, Madrid, 255-269. 
Fernández Galiano, D. et alii (1987): “La representación del Genio del Año en los mosaicos hispanorromanos", Cuadernos de Prehistoria y Arqueología 13-14, 175-183.

Fernández Ochoa, C. (2007): "Últimos trabajos arqueológicos en el yacimiento de Carranque (Toledo) 2004-2005”, [en] J. M. Millán - C. Rodríguez, C. (coords.), Arqueología de Castilla-La Mancha, Actas de las I Jornadas (Cuenca, 13-17 de diciembre de 2005), Cuenca, 743-753.

Foucher, L.

(1960): Inventaire des mosaïques de Sousse, Tunis.

(1981): "La représentation du Génie de l'Année sur les mosaïques", [en] Duval (ed.), 1981, 3-10.

Gabelmann, H. (1986): “Endymion”, LIMC III, Zürich-München, 726-742.

Gómez Pallarès, J. (1989): "Sobre un mosaico con inscripciones en Puente Genil (Córdoba)", Myrtia. Revista de Filología Clásica de la Universidad de Murcia 4, 105-116.

González, C. - El Amrani, T. (2013): Guía Arqueológica. Villa romana de Salar, Granada.

Gury, F. (1994): “Selene”, LIMC VII, Zürich-München, 706-715.

Hidalgo, R. (coord.), (2017): Las villas romanas de la Bética I-II (=Editorial Universidad de Sevilla. Serie Historia y Geografía 319), Sevilla.

Ibba, A. (2019): "Riflessioni sul mosaico nilotico di Fuente Álamo: dalle immagini alle parole", [en] Neira (ed.), 2019, 335-351.

Jiménez, J. C. et alii (1985): "Memoria de la excavación de urgencia en "El Alcaparral" (Casariche, Sevilla) 1985”, Anuario Arqueológico de Andalucía III, 274-276.

Jiménez Salvador, J. L. - Martín Bueno, M.

(1992): La Casa del Mitra, Cabra.

(2017): “Mitra (Cabra)", [en] Hidalgo (coord.), 2017, vol. II, 186-191.

Kondoleon, C.

(1991): The Mosaics of the House of Dionysos at Paphos: A Contribution to the Study of Roman Art, Harvard.

(1995): Domestic and Divine: Roman Mosaics in the House of Dionysos, Ithaca-London.

Kossatz-Deissmann, A. (1994): "Paris Iudicium", LIMC VII, 1/2, Zürich-München, 176-188.

Lancha, J. (2001): "La mosaïque du triomphe indien de Bacchus de la villa de Fuente Álamo (Puente Genil, Espagne)", [en] D. Paunier - C. Schmidt (eds.), La mosaïque grécoromaine VIII: Actes du VIIIème colloque international pour l'étude la mosaïque antique et medieval (Lausanne 6-11 octobre 1997), Lausanne, 161-176.

Levi, D. (1947): Antioch Mosaic Pavements, Princeton.

Lledó, J. L. (2010): Mosaico romano de Noheda (Cuenca): su descubrimiento, Madrid.

López Monteagudo, G. (2014): "El mosaico de "los Amores" de Cástulo", Siete Esquinas 6, 117-126.

López Monteagudo, G. - Neira, L. (2010): “Mosaico”, [en] P. León (coord.), Arte Romano de la Bética III, Madrid, 1-187.

López Monteagudo, G. - San Nicolás, Ma P. (2012-2013): “Afrodita-Venus en el Sur de Hispania. A propósito de un nuevo mosaico descubierto", Saitabi: revista de la Facultat de Geografia i Història 62-63, 19-25.

López Monteagudo, G. et alii (1988): "El simbolismo del matrimonio en el mosaico de Fuente Álamo (Puente Genil, Córdoba) y otros mosaicos hispanos inéditos", Latomus 47/4, 785-804.

López Palomo, J. A.

(1985): "Excavaciones de urgencia en la villa romana de Fuente Álamo (Puente Genil, Córdoba)", Anuario Arqueológico de Andalucía III, 105-111. 
(2013-2014): “Balneum y Villa. La secuencia romana de Fuente Álamo (Puente Genil, Córdoba)", Romvla, 12-13, 295-348.

Mañas, I. - Vargas, S. (2007): "Nuevos mosaicos hallados en Málaga: las villas de La Estación y de La Torre de Benagalbón”, Mainake 29, 315-338.

Memoria de Extracción de los mosaicos del yacimiento de la villa romana del Alcaparral. Casariche. Sevilla, realizada por GARES. S.L., Sevilla, 2000.

Neira, L.

(1992): La representación del thiasos marino en los mosaicos romanos. Nereidas y tritones, Tesis doctoral, Universidad Complutense de Madrid.

(1997): "Representaciones de nereidas. La pervivencia de algunas series tipológicas en los mosaicos romanos de la Antigüedad Tardía", Antigüedad y Cristianismo XIV, 363-402.

(2001): "Series tipológicas de nereidas propias de los mosaicos romanos del Norte de África", [en] S. Lancel (ed.), Numismatique, langues, écritures et arts du livre, spécificité des arts figurés, Paris, 327-342.

(2002): La representación del thiasos marino en los mosaicos romanos. Nereidas y tritones, Madrid.

(2008): "Las Tres Gracias en los mosaicos romanos", Bullettino della Commissione Archeologica Comunale di Roma. Supplementi 18, 287-300.

(2015): "Written and Visual Culture about the mosaic of Castulo", Journal of Mosaic Research 8, 61-79 (https://doi.org/10.26658/jmr.306315).

(2018a): "En torno al mosaico de los Amores de Castulo. A propósito de la vinculación del profesor Blázquez con los mosaicos romanos y Castulo", [en] N. Camarero (coord.), Vir validus et nobilis. Homenaje a D. José María Blázquez Martínez, Linares, 239-266.

(2018b): "On the Interpretation of Pothos in a Mosaic from the Antiquities Market with the Representation of Pelops and Hippodameia", Journal of Mosaic Research 11, 149154 (https://doi.org/10.26658/jmr.440574).

(2019): "Los mosaicos romanos del yacimiento rural de Fuente Álamo (Puente Genil, Córdoba): Investigación y puesta en valor", [en] Neira (ed.), 2019, 279-322.

(2020a): "Los mosaicos en las villae hispanas. El caso de Fuente Álamo (Puente Genil, Córdoba)", [en] J. d'Encarnação (ed.), Villae Romanas. Investigação e Inovação, Cascais, 47-63.

(2020b): "Los mosaicos de las villae bajoimperiales de Hispania. Reflexiones sobre algunos conjuntos de la Baetica, la Tarraconensis y la Carthaginensis", [en] Congreso Internacional "Las Villas Romanas Bajoimperiales de Hispania”, Palencia, 251-264.

Neira, L. (ed.), (2019): Mosaicos romanos en el espacio rural. Investigación y puesta en valor (=«L'Erma» di Bretschneider. Hispania Antigua. Serie Arqueologica 10), Roma.

Neira, L. et alii: (2016): "Mosaico con representación de nereidas en Zaragoza", [en] I. Aguilera Aragón et alii (eds.), De las ánforas al museo. Estudios dedicados a Miguel Beltrán Lloris, Zaragoza, 683-693.

Parrish, D.

(1981): “Annus-Aion in Roman Mosaics”, [en] Duval (ed.), 1981, 11-25.

(1984): Season Mosaics of Roman North Africa (=Archaeologica 46), Roma.

Pipili, M. (1990): "Hippodameia”, LIMC V, Zürich-München, 434-440.

Recio, A. (1973): “Una villa romana en Martos" [en] XII Congreso Arqueológico Nacional, Jaén, 625-647.

Reinach, S. (1922): Repertoire de peintures grecques et romaines, Paris.

Romero, M. - Vargas, S. (2017): "La Estación” (Antequera)", [en] Hidalgo (coord.), 2017, vol. II, 437-447. 
San Nicolás, $\mathrm{M}^{\mathrm{a}} \mathrm{P}$.

(2015): "Iconografía del Juicio de Paris en los mosaicos romanos", [en] J. García et alii (coord.), Navigare necesse est. Homenaje al Prof. José María Luzón, Madrid, 558-566. (2018): "Technical and Artistic Aspects of the Roman Mosaic of Castulo (Jaén, Spain)", Journal of Mosaic Research 11, 193-205 (https://doi.org/10.26658/jmr.440597).

Teatini, A. (2019): "Riflessioni sul mosaico nilotico di Fuente Álamo: il mosaico nel suo contesto", [en] Neira (ed.), 2019, 323-335.

Valero, M. A. (2013): "The late-antique villa at Noheda (Villar de Domingo García) near Cuenca and its mosaics", Journal of Roman Achaeology 26, 307-330 (https://doi. org/10.1017/S1047759413000172).

Vargas, S. (2013): Diseños geométricos en los mosaicos del Conventus Astigitanus, Tesis doctoral, Universidad Pablo Olavide.

Vargas, S. - López Monteagudo, G. (2017): “La decoración musiva”, [en] Hidalgo (coord.), 2017, vol. I, 419-441.

Vargas, S. et alii (2017): Mosaicos romanos de Écija (Sevilla), Madrid-Écija. 